\title{
Characterisation and Valorisation of the Moroccan Diatomite
}

\author{
Bahaj Hanane, Rahmouna Jihad, Berry Naima, Targhi Soukaina, Barhoun Nadia, \\ Bachiri Taoufiq Naima
}

Geosciences and Applications Laboratory ("LGA”), Faculty of Science Ben M’sik, Hassan II University of Casablanca, Sidi Othmane Casablanca, Morocco

Email: hanane.bahaj-etu@etu.univh2c.ma,nadiabarhoun@gmail.com,nadia.barhoun@univh2c.ma

How to cite this paper: Hanane, B., Jihad, R., Naima, B., Soukaina, T., Nadia, B., \& Naima, B. T. (2022). Characterisation and Valorisation of the Moroccan Diatomite. Journal of Geoscience and Environment Protection, 10, 109-134.

https://doi.org/10.4236/gep.2022.102008

Received: December 3, 2021

Accepted: February 25, 2022

Published: February 28, 2022

Copyright $\odot 2022$ by author(s) and Scientific Research Publishing Inc. This work is licensed under the Creative Commons Attribution-NonCommercial International License (CC BY-NC 4.0). http://creativecommons.org/licenses/by-nc/4.0/

\begin{abstract}
Morocco is known for the diversity of its natural resources. In particular, the mineral substances, diatomites, material relatively abundant but poorly exploited in Morocco. The aim of this work is to determine the geochemical and textural characteristics of the different diatomite deposits of north-eastern Morocco in order to compile a database with the different properties of these sediments. These data are valuable to guide the use and exploitation of this natural georesource. Samples from 3 deposits were characterised by different techniques of analysis: sedimentological (granulometry, calcimetry), chemical $(\mathrm{pH}, \mathrm{X}$-ray diffraction, infrared spectrometry and transmission electron microscopy coupled with EDX). We also performed thermogravimetric analysis of some samples. Results revealed that diatomite is a fine, moderately refractory material with a basic $\mathrm{pH}$. While, the $\mathrm{CaCo}_{3}$ content varies between different deposits. It is composed mainly of silica and has a well-developed porosity. In addition, thermogravimetric analysis revealed a loss of mass with temperature increase. A moderate variation in the chemical composition of the diatomite was observed from one deposit to another. Generally, we can stipulate that the diatomite from the Rif deposit is relatively a good quality. It has relatively the same physico-chemical properties as the neighbouring regions.
\end{abstract}

\section{Keywords}

Diatomite, Morocco, Physico-Chemical Characteristics, Thermogravimetric Analysis

\section{Introduction}

Diatomite, also known as "diatomeous earth", is a sedimentary rock formed 
mainly from the debris of the microscopic shells (frustules) of diatoms. These frustules of various forms are composed of silica, often in an amorphous state (Breese, 1994). The Late Miocene represents one of the periods of high accumulation of biogenic silica in the world (El Ouahabi et al., 2007). This biosiliceous event is marked by the diatomite deposition during the Messinian in the Mediterranean domain (Pestrea et al., 2002; Saint Martin \& Rouchy, 1990; Cornée et al., 1996; El Ouahabi et al., 2007). The global increase in the production of silica as opal during the late Miocene, worldwide and in the Mediterranean area, has been explained by the synergistic intervention of abiotic (tectonic and climatic reconfigurations) and biotic (expansion of opal-rich biomasses) controlling factors (Pellegrino et al., 2018).

In Morocco, diatomitic deposits represent one of the phases of Messinian sedimentation relatively well represented in the north-eastern Rif. They are exposed as amarno-diatomitic alternation in the Nador and El Hoceima areas. These sediments have been the subject of several geological studies (Houzay, 1975; Rouchy \& Freinex, 1979; Guillemin \& Houzay, 1982; Rouchy, 1982; Wernli, 1988; Barhoun \& Wernli, 1999; Barhoun, 2000, Saint Martin et al., 2003, Van Assen et al., 2006). These studies have mainly allowed us to precise the biostratigraphic framework and to propose a paleoenvironmental interpretation of these sediments. As well as a scientific interest, diatomite is an environmentally friendly, inexpensive material and it's used in various environmental and industrial applications as a filter (Rocher, 1995; Ibrahim \& Selim, 2011), filler, abrasive, adsorbent (Zaitan et al., 2006; Colin et al., 2018) and catalyst (Sahraoui et al., 2002; Liu et al., 2004; Bahramian et al., 2008). The world production is around 3 million tonnes a year (Negroni, 2007; Colin et al., 2018).

However, in nature, this material is often associated with impurities that can affect its application. An impure diatomite is not useful as a filtering agent but can be used as a high quality absorbent product (Rocher, 1995).

In comparison to other mineral substances, research on the characterisation and valorisation of diatomite is not very developed in Morocco. Moreover, the previous studies realized on the diatomite of North-Eastern Morocco have been focused mainly on the Ras Tarf deposit (Agdi et al., 2000; Rizki et al., 2003; Haddad et al., 2001; Sahraoui et al., 2002; Zaitan et al., 2006).

The objective of this work is the physico-chemical characterisation of diatomites sampled in different North-Eastern Morocco deposits in order to establish a dataset with the different properties of these materials. These data are useful to making their exploitation more rigorous and rational.

This study provided information on the geochemical and textural characteristics of three diatomite deposits from north-eastern Morocco. It revealed a moderate variation in the chemical composition from one deposit to another.

\section{Geological Setting}

The diatomite deposits are exposed in the post nappe basins of north-eastern 
Morocco. These Neogene basins were formed after the main orogenic movements of the Rif (Guillemin \& Houzay, 1982). The Neogene series are deposited by a major angular unconformity on all the subjacent terrains. The diatomites are located in the Boudinar and Mellilia-Nador basins.

The Boudinar basin is a vast triangle open to the Mediterranean Sea in the north (Figure 1). It is limited to the west by the Trougout mountains (Ketama unit) and the RasTarf volcano, to the east by the Beni-Said massifs and to the south by the Beni Touzianes ridges. It was formed overlying the Kétama and Temsamane metamorphic nappes, or over the Middle Miocene-aged RasTarf volcanic massif (Achalhi et al., 2016).

Following its individualisation in the Early Tortonian, marine infilling of the basin began in the Tortonian and lasted until the Early Pliocene (Guillemin \& Houzay, 1982; Wernli, 1988; Barhoun \& Wernli, 1999; Azdimousa et al., 2006).

The Late Neogene deposits of the Boudinar Basin are organized into three sedimentary series that are differentiated by their facies and biostratigraphic characteristics (Guillemin et Houzay, 1982; Wernli, 1988; Ben Moussa, 1994; Barhoun et Wernli, 1999; Azdimousa et al., 2006, Achalhi et al., 2016). The Tortonian sedimentary series is composed of continental conglomerates followed by marine marls. In the early Messinian, the sedimentation is represented by marls with volcanic intercalations, diatomites and Porites coral reef layers (Saint Martin, 1990). These sediments are overlapped by a thick conglomeratic series attributed to the

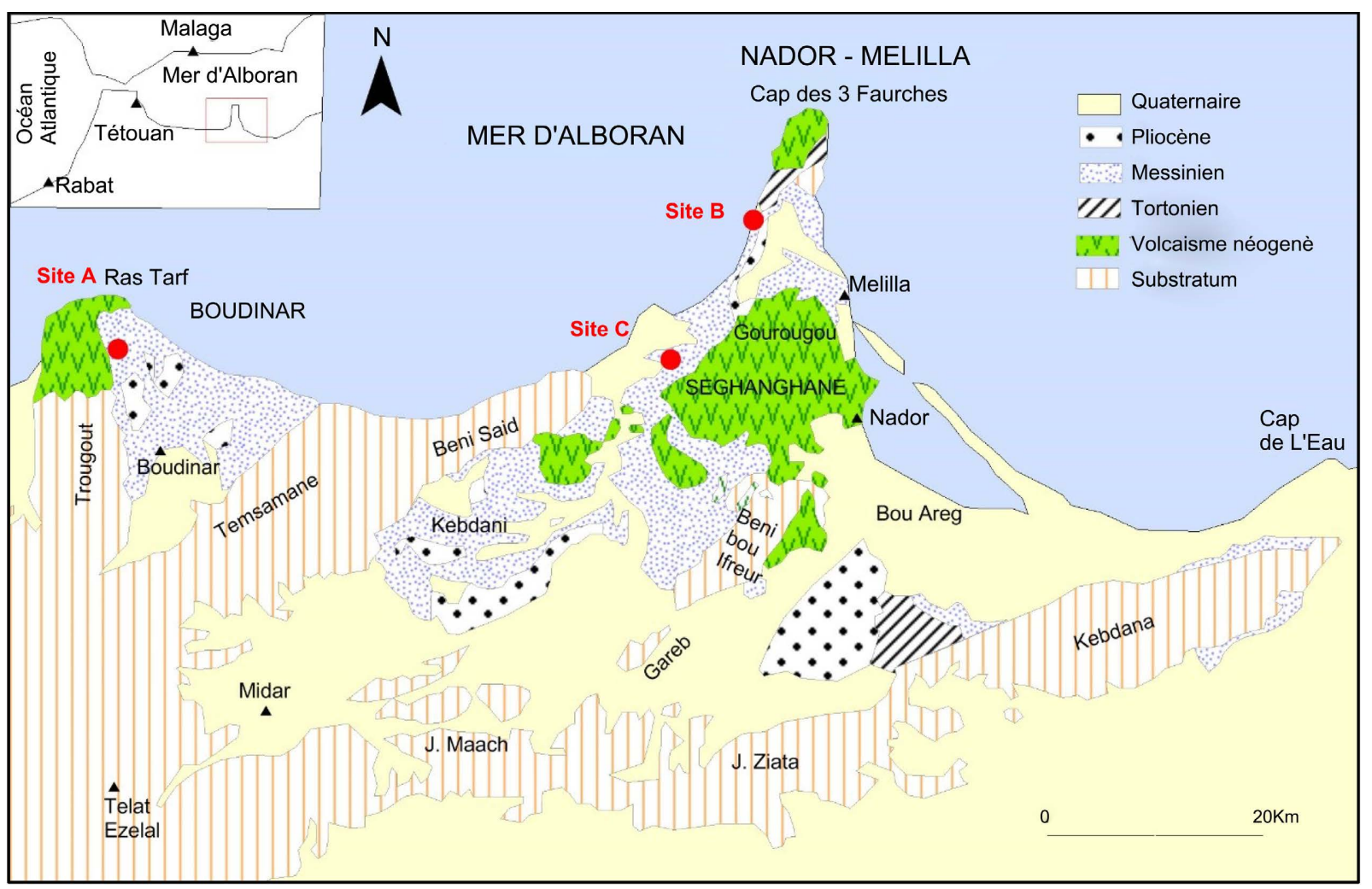

Figure 1. Simplified geological map of North Eastern Morocco (after El Hajjaji, 1992) and location of the sites studied: Site A (Boudinar), Site B (Cap des trois fourches) and site C (Zeghanghane). 
late Messinian (Achalhi et al., 2016; Cornée et al., 2016). The early Pliocene sedimentary series consists of marine sandy and marly deposits.

The diatomite sedimentation is mainly located in the north-western part of the basin. Several studies have been conducted on these sediments (Houzay, 1975; Guillemin \& Houzay, 1982; El Kharim, 1991; Rachid et al., 1997; Wernli, 1988; Barhoun \& Wernli, 1999; El Ouahabi et al., 2007) which have established their biostratigraphic and paleoenvironmental context.

The Melilla-Nador basin is located along the north-eastern coast of Morocco, and is bounded to the north by the rhyolitic complex of the Cap des Trois Fourches and to the south by the Gourougou volcanic massif. It extends to the valley of the Oued Kert in the west.

The Tortonian and Messinian sediments are largely transgressive on the substratum.

The Messinian sedimentation is characterised by the development of a carbonate platform located on the Cap des Trois Fourches which constitutes a very extensive sedimentary complex, passing southwards into open marine marls, diatomites and volcanic-clastic deposits in the vicinity of the Gourougou volcanism (Cornée et al., 2002).

The diatomite deposits from the Melilla-Nador Basin are mainly located on the periphery of the carbonate plateform and outcrop in the eastern and western parts of the Trois Fourches peninsula (Saint Martin et al., 2003).

\section{Materials and Methods}

The diatomite samples were collected from three deposits located in North Eastern Morocco: Boudinar (A), Cap des trois fourches (B) and Zeghanghane (C). The samples were collected in thick and homogeneous diatomite levels.

Diatomite is an important industrial material with special properties (Breese, 1994). In order to determine the physico-chemical characteristics of the samples, we used the analytical techniques commonly adopted to characterise this material (Stamatakisa \& Koukouzas, 2001; Arik, 2003; Sahraoui et al., 2002).

First, we measured the $\mathrm{pH}$ and the $\mathrm{CaCO}_{3}$ content for each sample.

To measure the $\mathrm{PH}, 20 \mathrm{~g}$ of the diatomite is placed in a beaker then $100 \mathrm{ml}$ of distilled water is added. The solution obtained is agitated for 15 to $20 \mathrm{~min}$ by a magnetic agitator. Then measurements of each sample are taken by a $\mathrm{pH}$ meter Type HI $2211 \mathrm{Ph} / \mathrm{ORP}$ Meter.

Calcimetry was determined using the Bernard calcimeter method. The determination of the percentage of $\mathrm{CaCO}_{3}$ is done with reference to a control test with a mass $\mathrm{mt}(=0.25 \mathrm{~g})$ of pure $\mathrm{CaCO}_{3}$ which emits a volume $\mathrm{Vt}$ of $\mathrm{CO}_{2}$ after reaction with excess $\mathrm{HCl}$.

We also performed the granulometric analysis of all the samples to know the size of the grains of the diatomite. The granulometry consists in classifying the various grains constituting the sample by using a series of sieves, assembled the ones on the others, whose dimensions of the openings are decreasing from the 
top to the bottom. $100 \mathrm{~g}$ of each sample is sieved in a series of sieves under water; the residues are recovered and weighed.

The phase identification was performed using X-ray diffraction (XRD) where the Diffractograms were executed by $X^{\prime}$ Pert Pro and were recorded by $X^{\prime}$ Pert High Score. The incident radiation is given by the copper $\mathrm{Ka}$ line $(\lambda=1.54060$ $\AA$ ), operated at a tube voltage of $45 \mathrm{kv}$ and a tube current of $40 \mathrm{Ma}$.

The determination of the nature of the functional groups and molecular bonds present in the samples studied is realized by infrared spectrometry. This technique also supports the results of the X-ray diffraction. The analysis is made using a Fourier transform spectrometer, which sends infrared radiation onto the sample and measures the wavelengths at which the material absorbs and the intensities of the absorption. Fourier transform infrared spectra were registered between 400 and $4000 \mathrm{~cm}^{-1}$ by a Bruker Tensor- 27 spectrometer with a resolution of $2 \mathrm{~cm}^{-1}$. The study was done on a ground sample, then mixed with potassium bromide (KBr) in pellet form (1/200 by weight).

Morphological and microstructural characterisation of crude diatomite was performed by scanning electron microscopy (SEM) using a Quattro S FEG instrument with a $1.2 \mathrm{~nm}$ resolution field emission gun (FEG) source, SE detectors (ETD,GSED), BSE, and EDS microanalysis (129 eV resolution).

The thermal properties of the diatomite are determined by thermogravimetric analysis (TGA). The samples are finely ground $(63 \mu \mathrm{m})$, the mass used for the Boudinar sample (A1) is $76 \mathrm{mg}$ and for the Cap des trois fourches sample (B1) is $69 \mathrm{mg}$. The powder to be analysed is placed in the sample cup, the stove starts to heat and the temperature rise is observed from ambient temperature to $1200^{\circ} \mathrm{C}$. Evolution of diatomite mass loss is controlled by the SetsysEv 1750 (TGA 1750 ${ }^{\circ}$ ) instrument.

\section{Results}

In this section, the analytical results obtained by different techniques are presented and analysed.

\subsection{Sedimentological Analysis}

\subsubsection{Granulometry}

The particle size parameters of the studied samples are consigned in Figure 2. The average grain size of the studied samples showed values below $63 \mu \mathrm{m}$ across all deposits. It demonstrates the fine to very fine character of diatomite, as illustrated by the frequency histograms (Figure 2). Thus, this material has almost the same particle size characteristics as the diatomite from Ras Tarf (Haddad et al., 2001) and Algeria (Benzelmat et al., 2019).

\subsubsection{Calcimetry}

The diatomites carbonate content of the studied samples is expressed in the histograms in Figure 3. Globally, $\mathrm{CaCO}_{3}$ contents fluctuate between 3 and 27.73\%. Samples from Cap des trois Fourches contain the highest percentage in carbonate. 


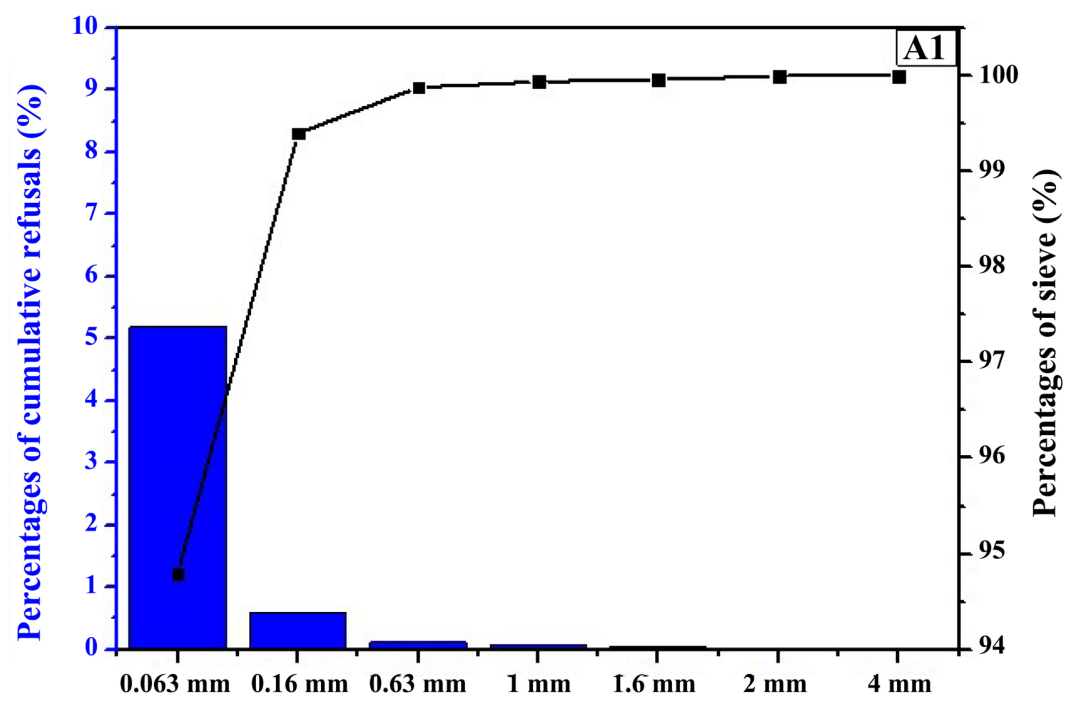

Sieve openings in (mm)

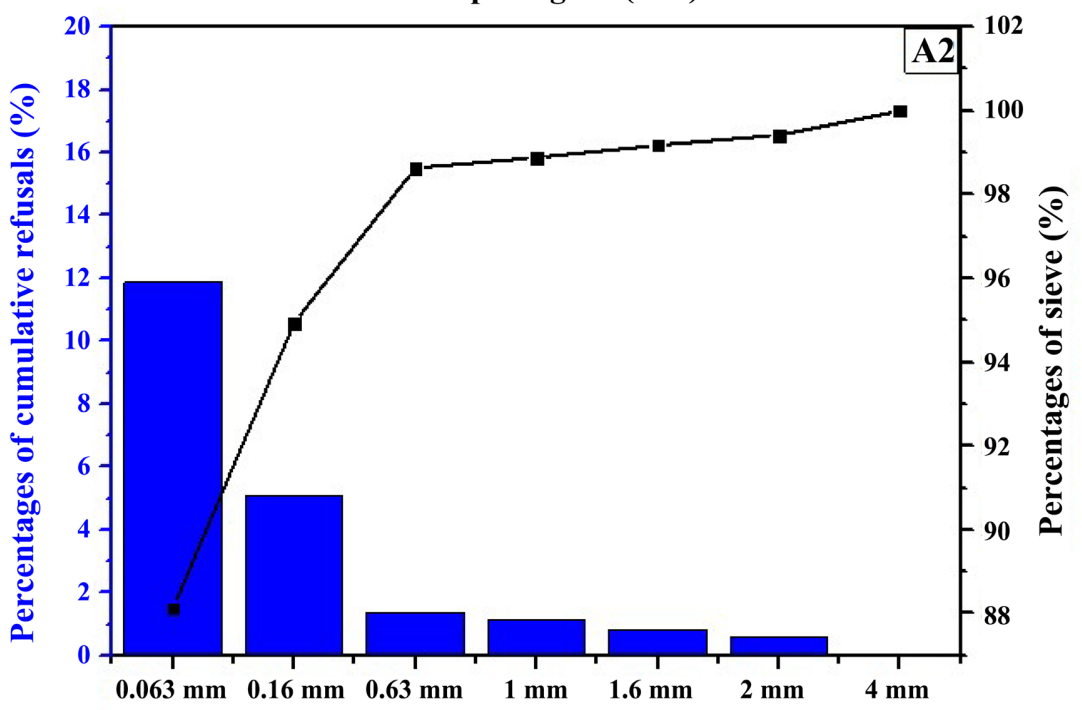

Sieve opening in ( $\mathrm{mm})$

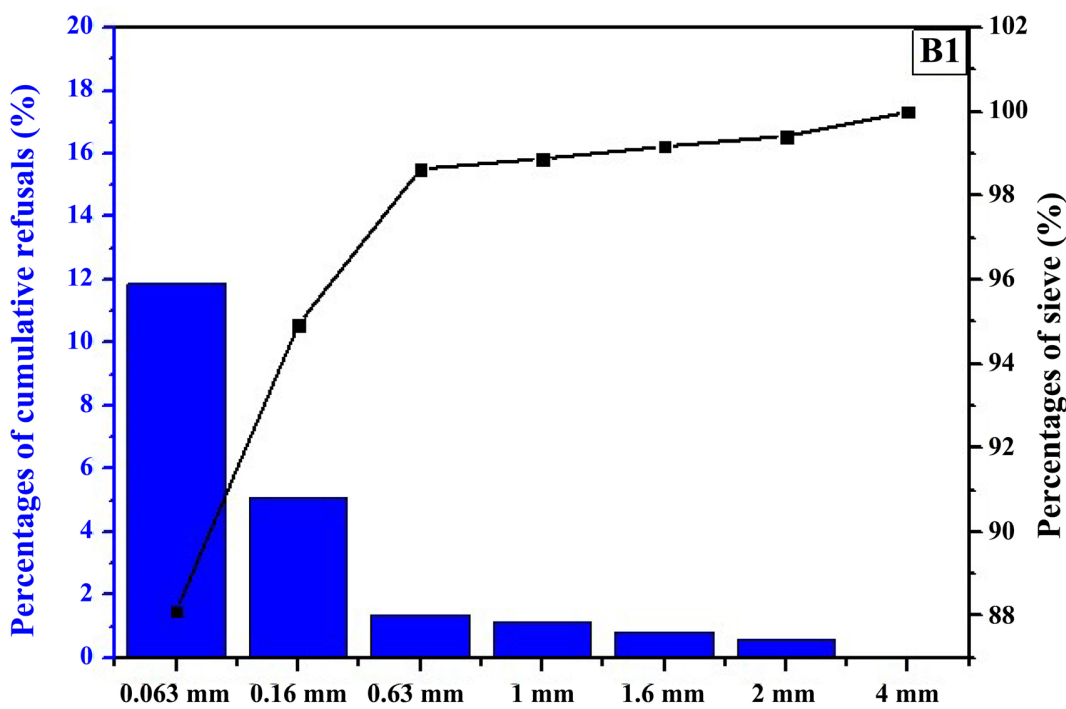

Sieve opening in ( $\mathrm{mm})$ 


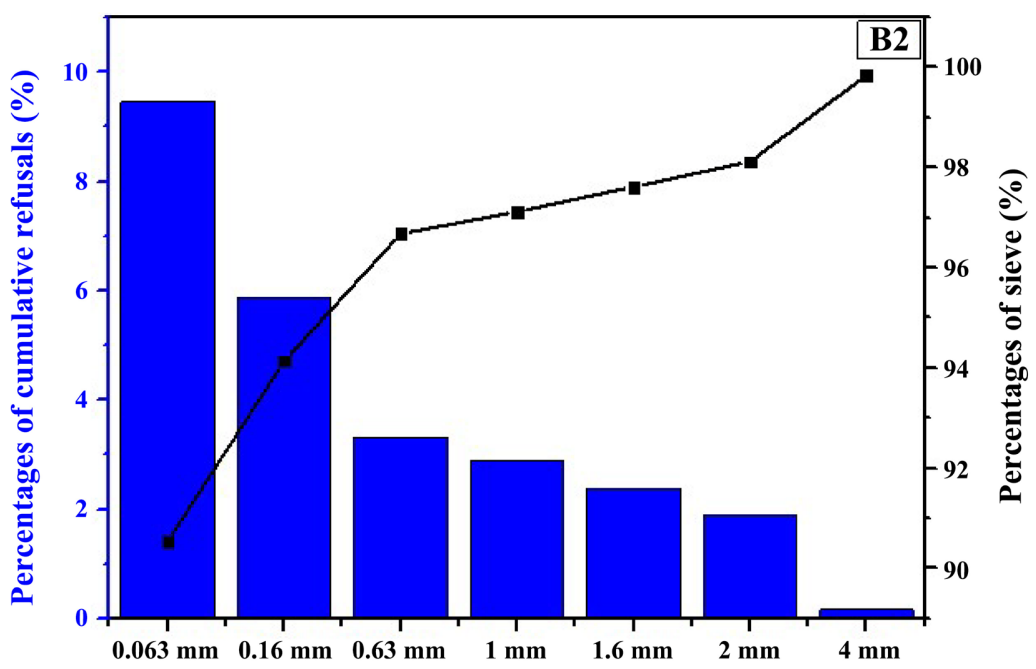

Sieve opening in $(\mathrm{mm})$

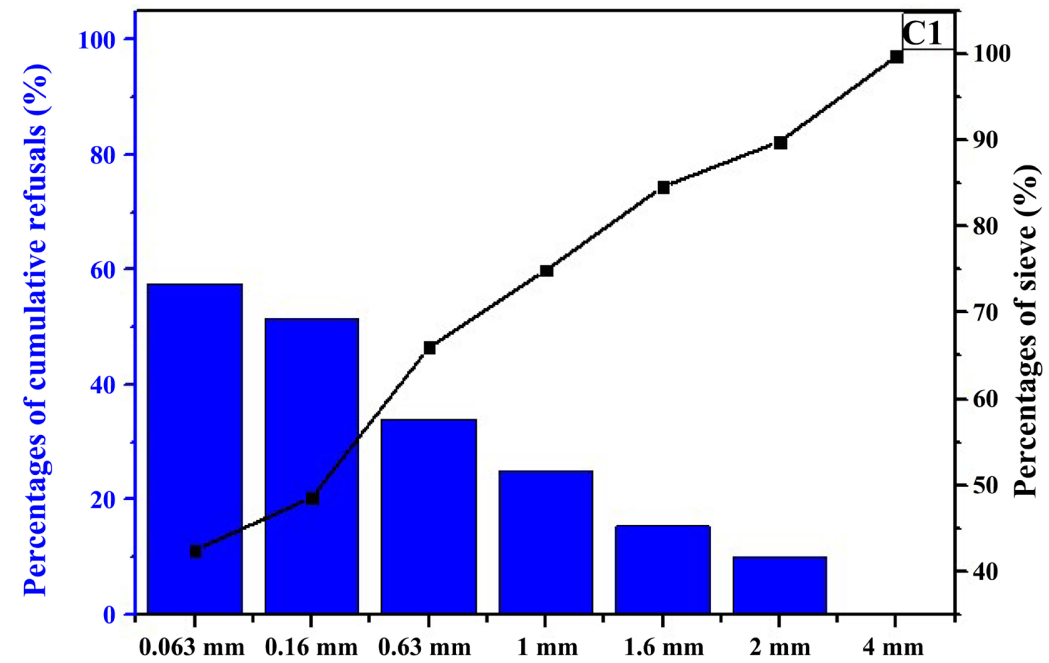

Sieve opening in $(\mathbf{m m})$

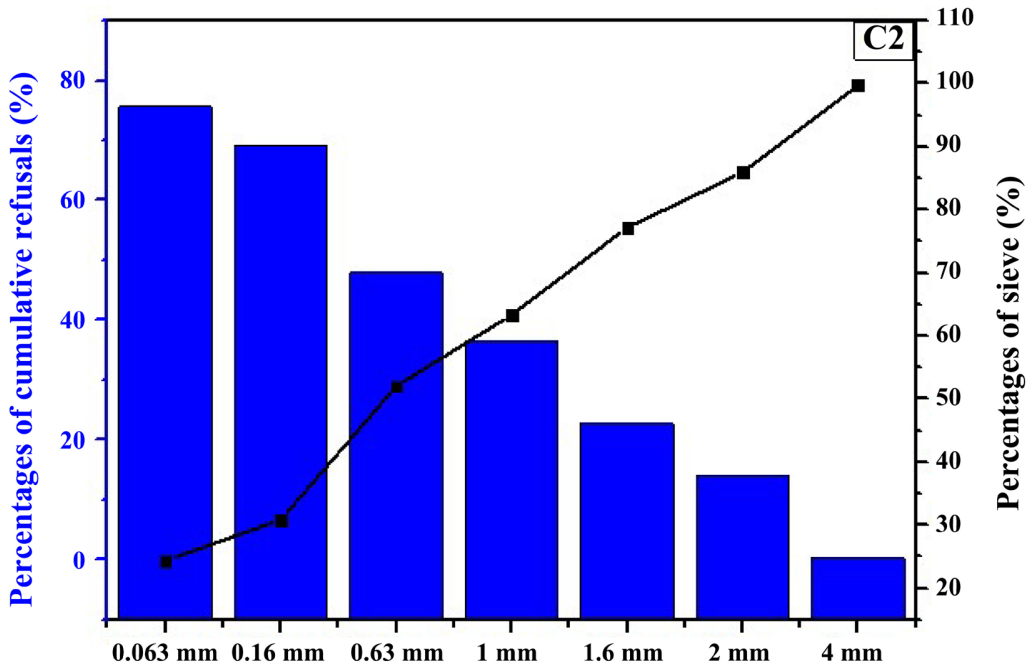

Sieve opening in $(\mathrm{mm})$

Figure 2. Granulometry histogram of Samples from Boudinar (A1, A2), Cap des trois Fourches (B1, B2) and Zeghanghane (C1, C2). 


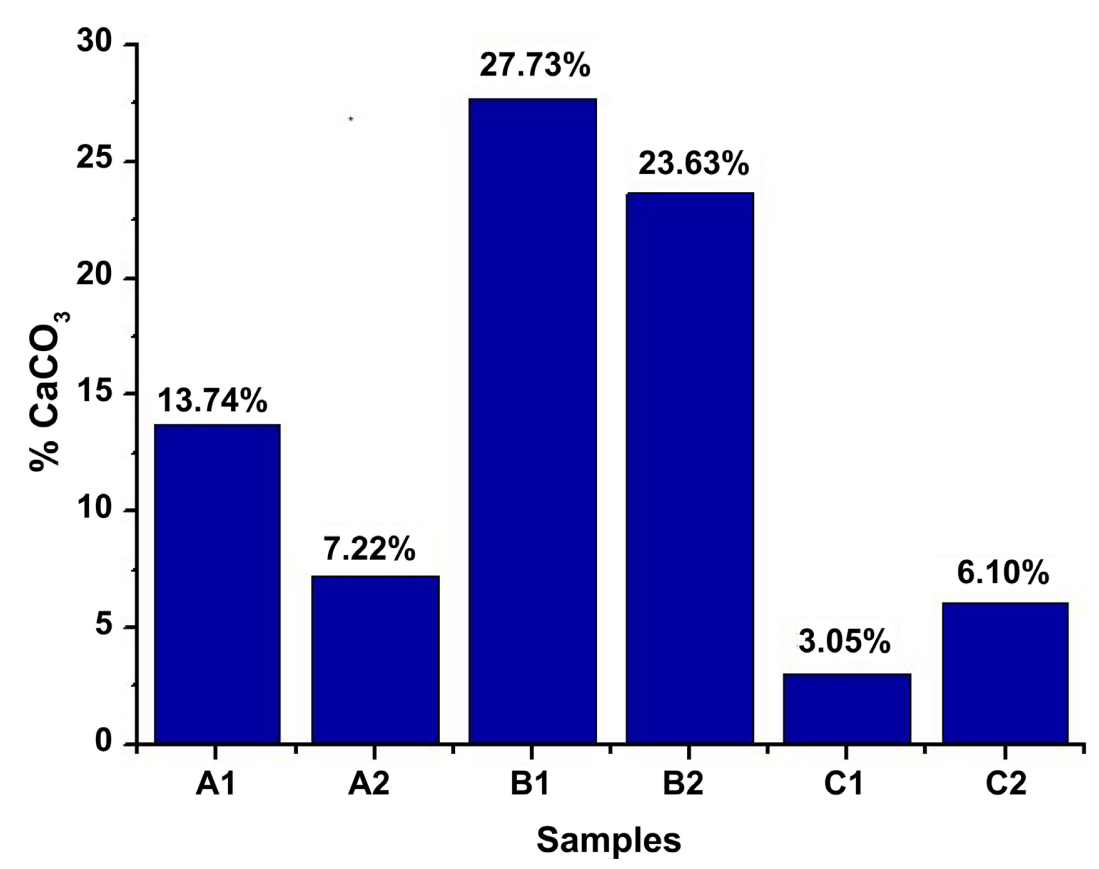

Figure 3. Histogram for the percentage of carbonates of the crude diatomite in Boudinar (A1, A2), Cap des trois Fourches (B1, B2) and Zeghanghane (C1, C2).

Variation in the calcium carbonate $\mathrm{CaCO}_{3}$ content of the various samples allows us to distinguish two types of facies: carbonated diatomite, the Cap des 3 fourches deposit, with a content of up to $28 \%$; and less carbonated diatomite, the Boudinar and Zeghanghane diatomite, where the content varies between 3\% and 14\%. The diatomite from the Cape des Trois Fourches presents approximately the similar composition as the Algerian diatomite (Benzelmat et al., 2019). However, the diatomite of Boudinar and Zeghanghane has more affinity with the Ras Tarf diatomite (Haddad et al., 2001; Zaitan et al., 2006). Thus, exploitation of diatomite from the Cape des Trois Fourches requires prior treatment to eliminate impurities and improve the quality of the material.

\subsection{Physico-Chemical Analysis}

\subsection{1. $\mathrm{pH}$}

In general, the $\mathrm{pH}$ of natural diatomite is in the range of 7 to 8 (Rocher, 1995). The $\mathrm{pH}$ values of the raw diatomite from the deposits studied oscillate between 7.61 and 7.83 (Figure 4). This material is comparable to diatomite from Sig (Algeria), which presents a pH of 7.9 (Cherrak, 2018).

\subsubsection{X-Ray Diffraction (XRD)}

The X-ray diffraction results of the crude diatomite from the three deposits are presented on Figure 5. The x-ray diffraction spectrum shows that the crude diatomite of the Boudinar deposit consists mainly of silica in two forms Quartz $\left(\mathrm{SiO}_{2}\right)$ located at 2 theta $=20^{\circ}, 42^{\circ}$ and amorphous silica observed at 2 theta $=$ $10^{\circ}$ to $19^{\circ}$. In addition, characteristic peaks of carbonate minerals such as calcite $\left(\mathrm{CaCO}_{3}\right)$ located at 2 theta $=23^{\circ}, 36^{\circ}$, dolomite $\left(\mathrm{Ca} \mathrm{Mg}\left(\mathrm{CO}_{3}\right)\right)$ at 2 theta $=30^{\circ}$ 


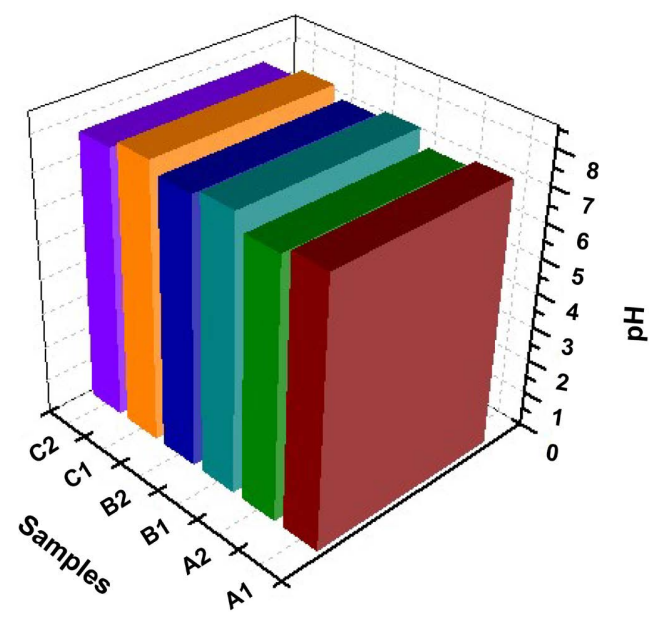

Figure 4. $\mathrm{pH}$ histogram of the crude diatomite in Boudinar (A1, A2), Cap des trois forches (B1, B2) and Zeghanghane (C1, C2).
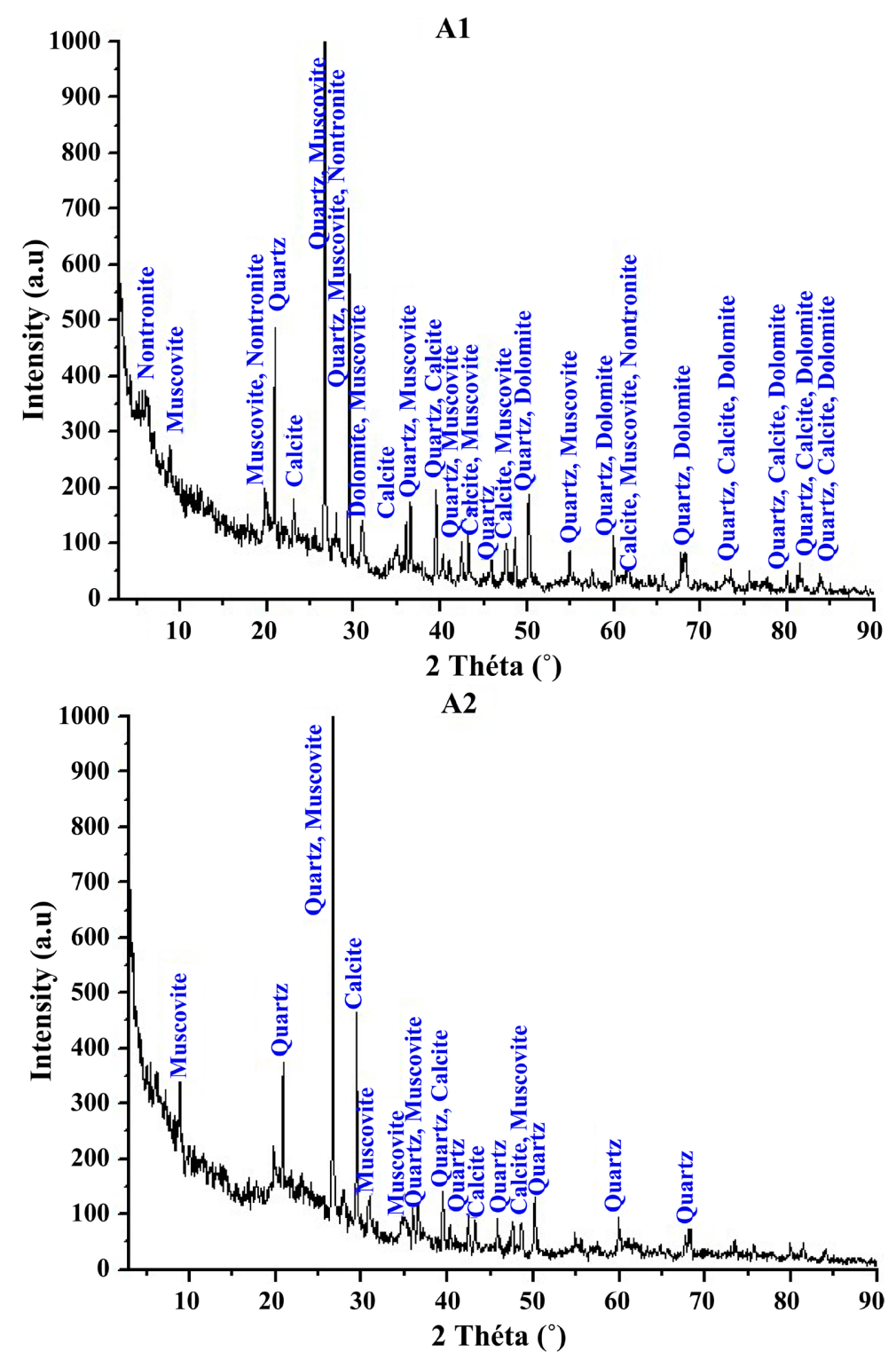
B1
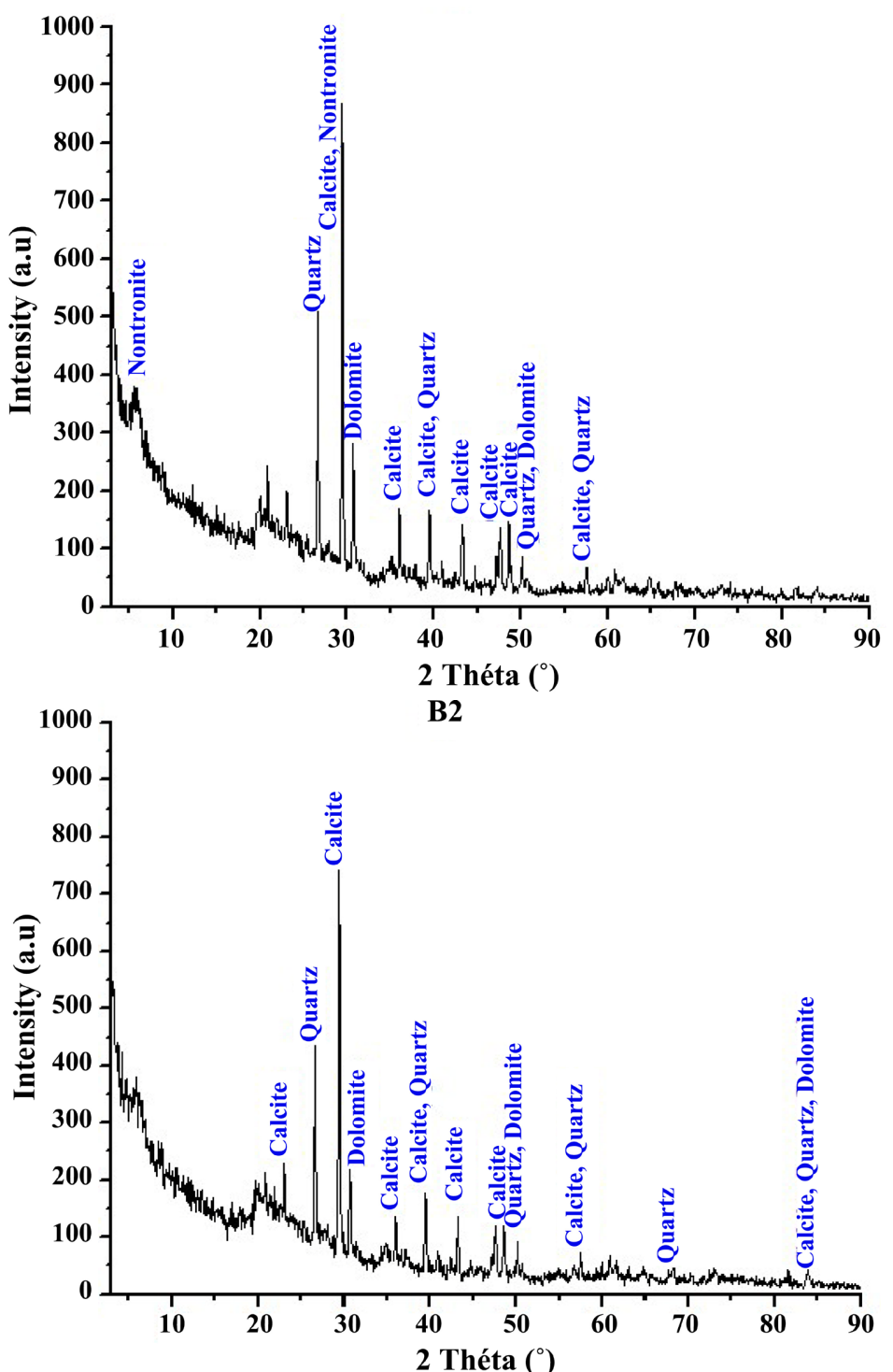

C1

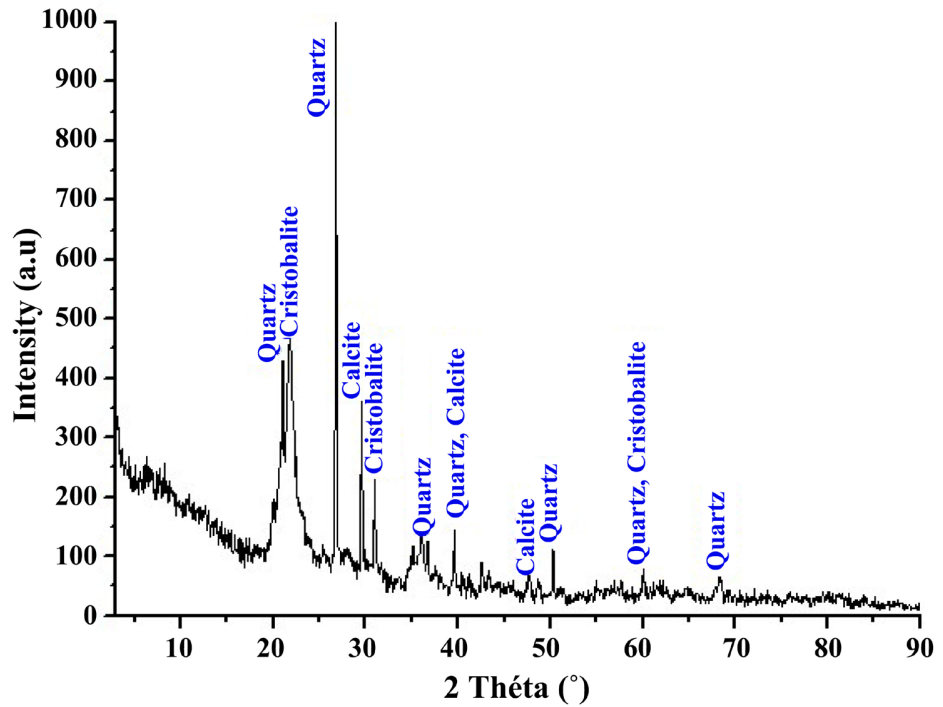




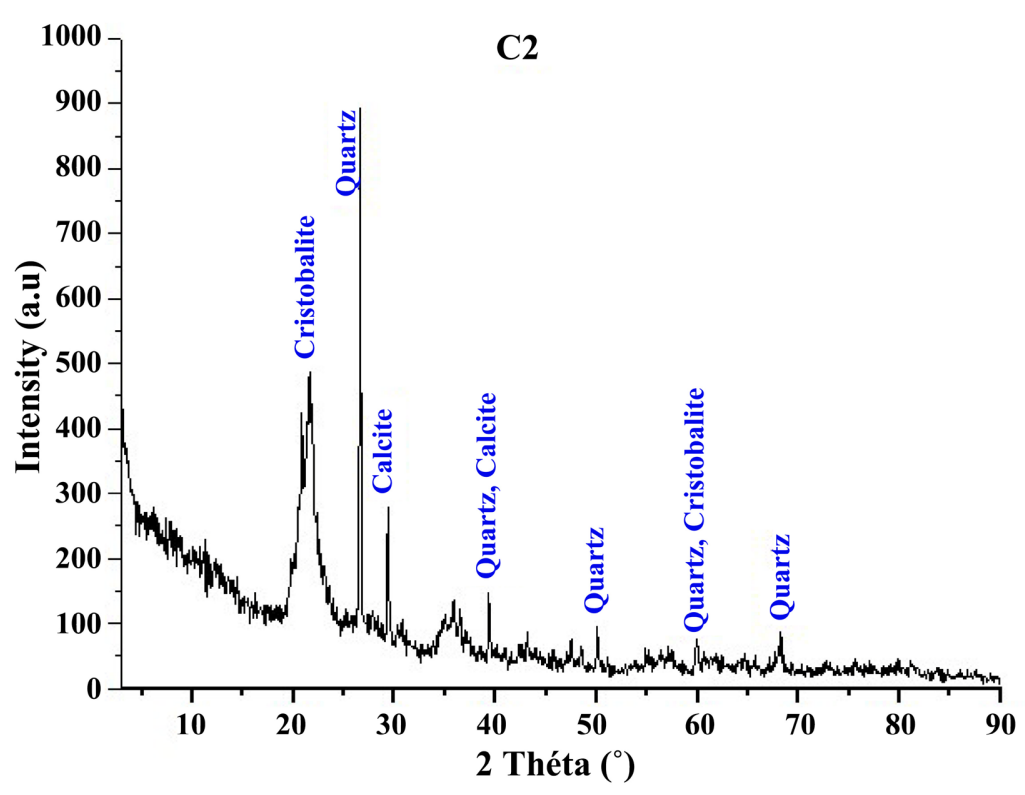

Figure 5. X-ray diffractograms of the X-ray diffraction of the crude diatomite in Boudinar (A1, A2), Caps des trois Fourches (B1, B2) and Zeghanghane (C1, C2).

and clay minerals (Muscovite 2 theta $=8^{\circ}$ and Nontronite 2 theta $=5^{\circ}$ ). While the diffractograms of the diatomite samples from Cap des trois Fourches show that the predominant peaks are those of silica as Quartz $\left(\mathrm{SiO}_{2}\right) 2$ theta $=26^{\circ}$, and amorphous silica 2 theta $=10^{\circ}$ to $19^{\circ}$. Next, carbonate minerals such as calcite $\left(\mathrm{CaCO}_{3}\right)$ located at 2 theta $=23^{\circ}, 29^{\circ}, 43^{\circ}, 47^{\circ}, 48^{\circ}$ and Dolomite $\left(\mathrm{Ca} \mathrm{Mg}\left(\mathrm{CO}_{3}\right)\right)$ located at 2 theta $=30^{\circ}$. Finally, clay minerals represented by Nontronite are also observed.

$\mathrm{X}$-ray phase analysis of the Zeghanghane basin samples show the predominance of silica as cristobalite $\left(2\right.$ theta $\left.=22^{\circ}, 31^{\circ}\right)$, Quartz $\left(2\right.$ theta $\left.=27^{\circ}, 36^{\circ}\right)$ and amorphous silica $\left(2\right.$ theta $=10^{\circ}$ to $19^{\circ}$ ). X-Ray signals corresponding to the crystalline form of $\mathrm{CaCO}_{3}$ are as Calcite $\left(2\right.$ theta $\left.=29^{\circ}\right)$.

\subsubsection{Infrared Spectrometry}

The IR spectra obtained for the crude diatomite from the three deposits are shown in Figure 6. They indicate the presence of bands at about 3627, 3439, $1638 \mathrm{~cm}^{-1}$ which could be attributed to the vibration bands of the valence bonds of the O-H water molecules adsorbed on the surface of free silica. We also observed the presence of the characteristic bands of carbonate ions $(2515,1436$, $\left.713,875 \mathrm{~cm}^{-1}\right)$. As for the bands $\left(474,1086 \mathrm{~cm}^{-1}\right)$, the recorded spectrum shows intense absorption bands between 1000 and $1100 \mathrm{~cm}^{-1}$ and at $797 \mathrm{~cm}^{-1}$ attributed to the stretching bands of Si-O-Si vibrations. The bands at about $797 \mathrm{~cm}^{-1}$ correspond to the Al-O-Si vibration of the Si-OH silica. A band of around 692 $\mathrm{cm}^{-1}$ characterises the elongation vibrations of the Al-O bond. Moreover, the bond observed around $524 \mathrm{~cm}^{-1}$ is attributed to the deformation vibration of the $\mathrm{Al}-\mathrm{O}-\mathrm{Si}$ band. Finally, the bands of about $458 \mathrm{~cm}^{-1}$ could be attributed to the symmetrical and asymmetrical vibrations of the Si-O bond and the Si-OH silica. 

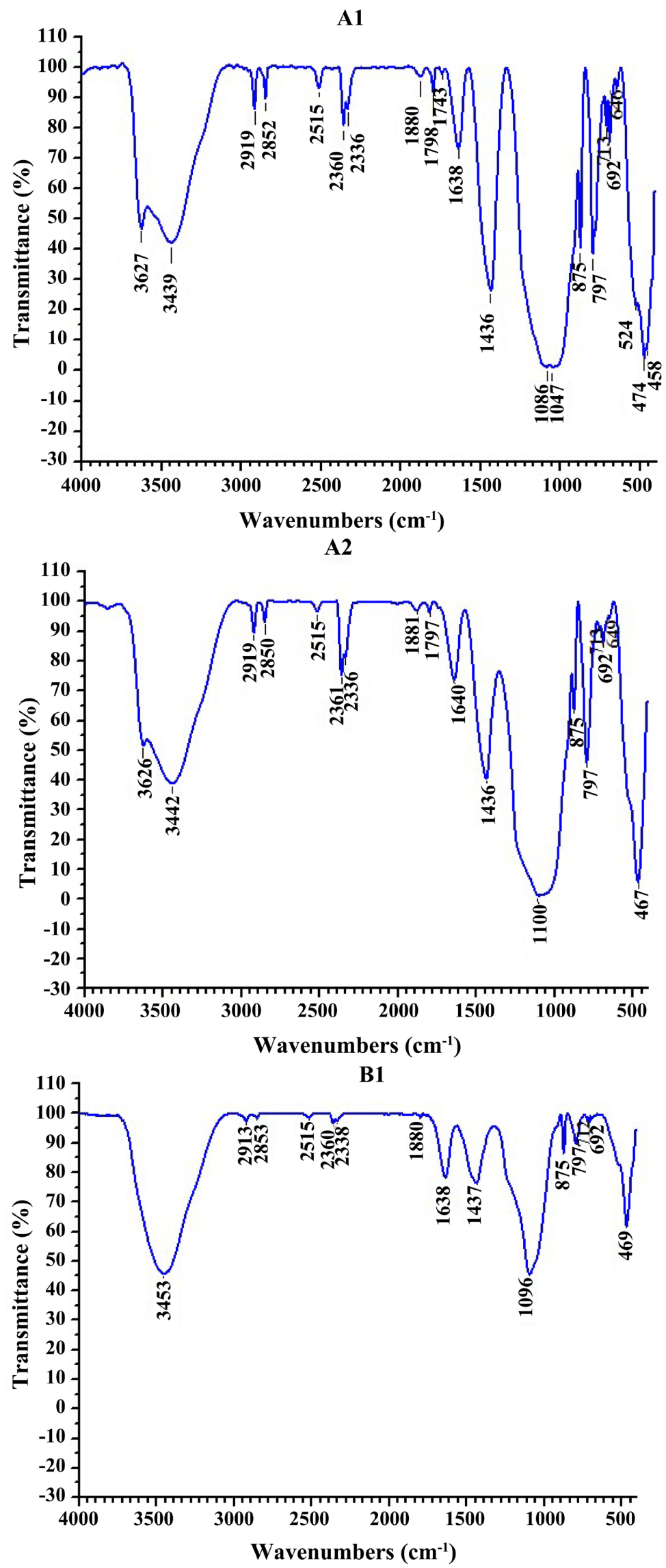

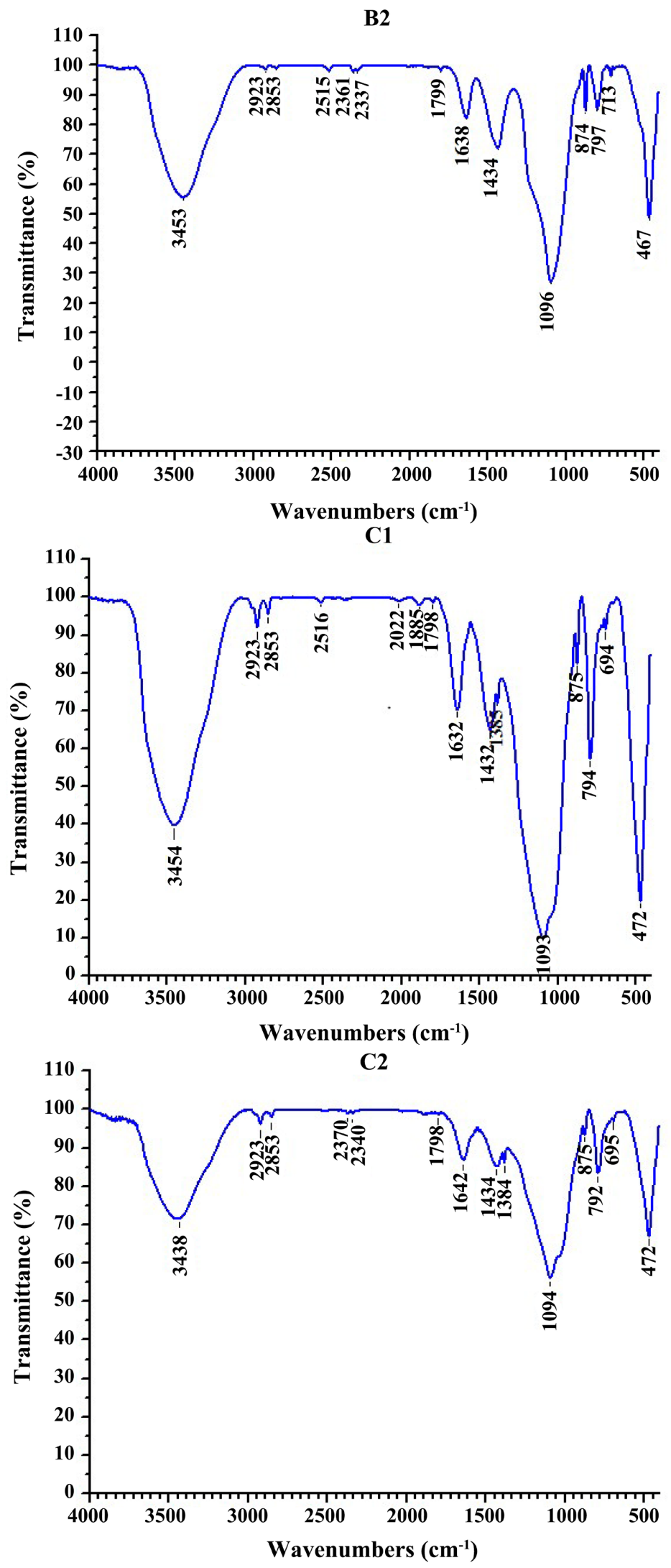

Figure 6. Infrared spectra of the crude diatomite in Boudinar (A1, A2), Cap des trois Fourches (B1, B2) and Zeghanghane (C1, C2). 


\subsubsection{Scanning Electronic Microscope}

Scanning electron microscope analysis of raw diatomite from two deposits in the North Eastern Rif (Boudinar and Cap des trois fourches) reveals that this material is mainly composed of fossilised diatoms. They are represented by whole skeletons and their large fragments. Images of the crude diatomite are illustrated in Figure 7 and Figure 8. They show that the diatoms have a circular shape with a multi-porous structure. The pores are uniformly distributed over the test surface.
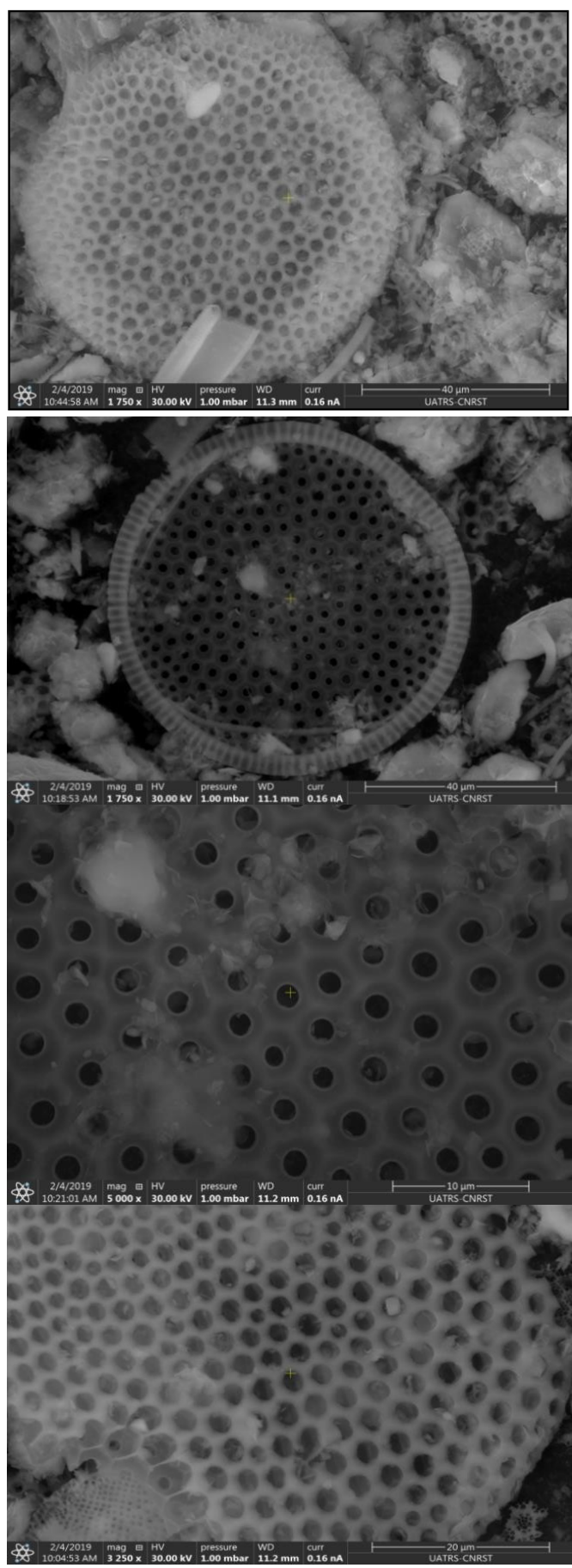

Figure 7. Aspect of Boudinar crude diatomite texture and pore structure. 


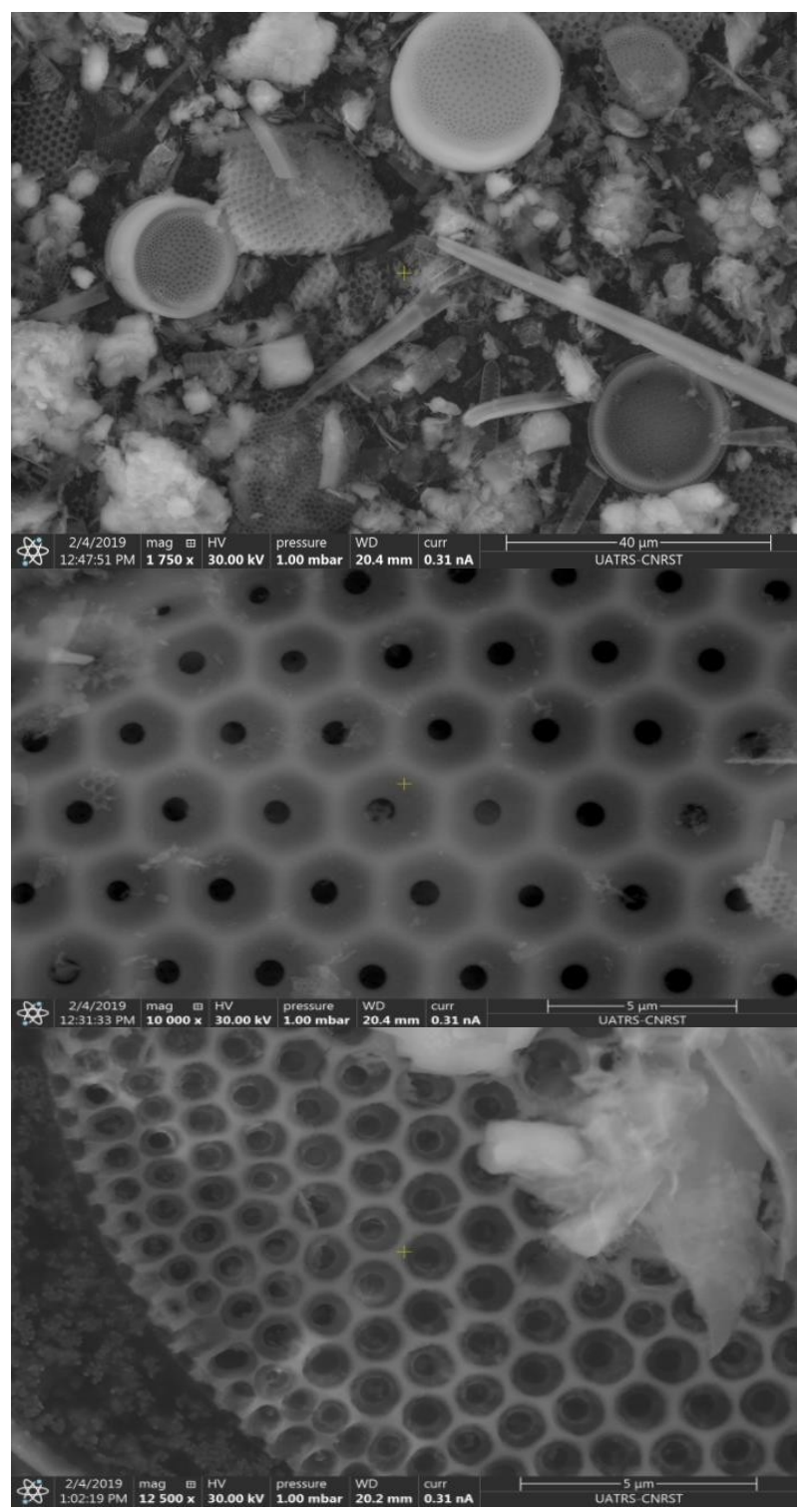

Figure 8. Aspect of Cap des trois Fourches crude diatomite texture and pore structure.

According to the results of chemical composition obtained by SEM (Figure 9 and Figure 10), we have observed that the crude diatomites are composed of a large proportion of $\mathrm{Si}$ as shown by the large peak of silica, followed by $\mathrm{Al}, \mathrm{Ca}$ and $\mathrm{Mg}$ and a small amount of $\mathrm{Fe}, \mathrm{Na}$ and $\mathrm{K}$.

\subsubsection{Thermogravimetric Analysis}

ATG thermogravimetric analysis consists of a continuous following of the diatomite comportment at different temperatures according to a determined law. The thermogravimetric curves of the crude diatomites studied are indicated in Figure 11. The analysis of the thermograms of the Boudinar samples reveals two distinct mass losses: The first, moderate, took place at $400^{\circ} \mathrm{C}$, it is about $4.73 \%$ for $\mathrm{A} 1$ and $5.78 \%$ for $\mathrm{A} 2$. The second, more important loss was observed at $1070^{\circ} \mathrm{C}$. It corresponds to $11.64 \%$ for A1 and $8.84 \%$ for A2. Concerning the Cap 


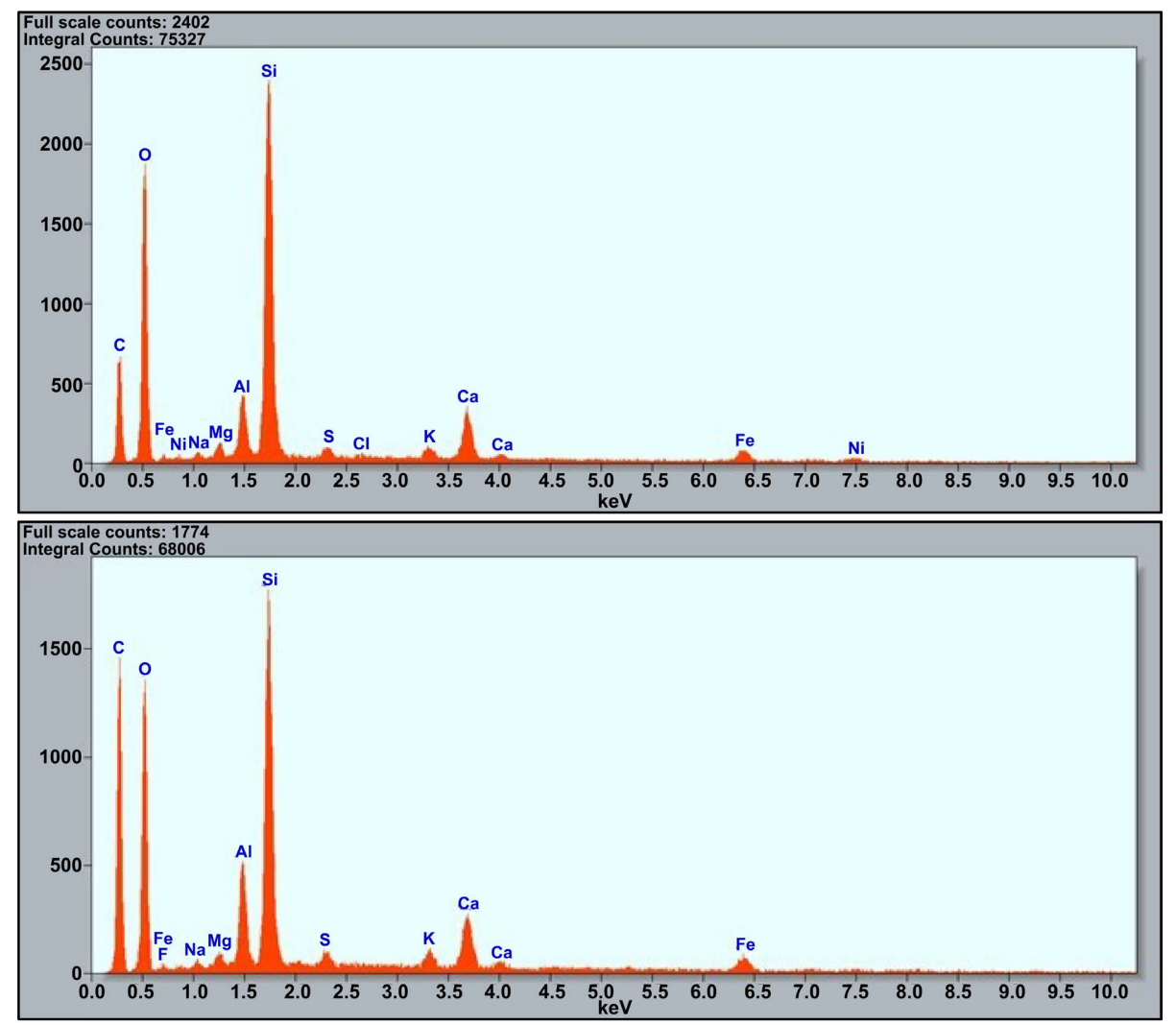

Figure 9. Chemical composition of Boudinar diatomite obtained by SEM.

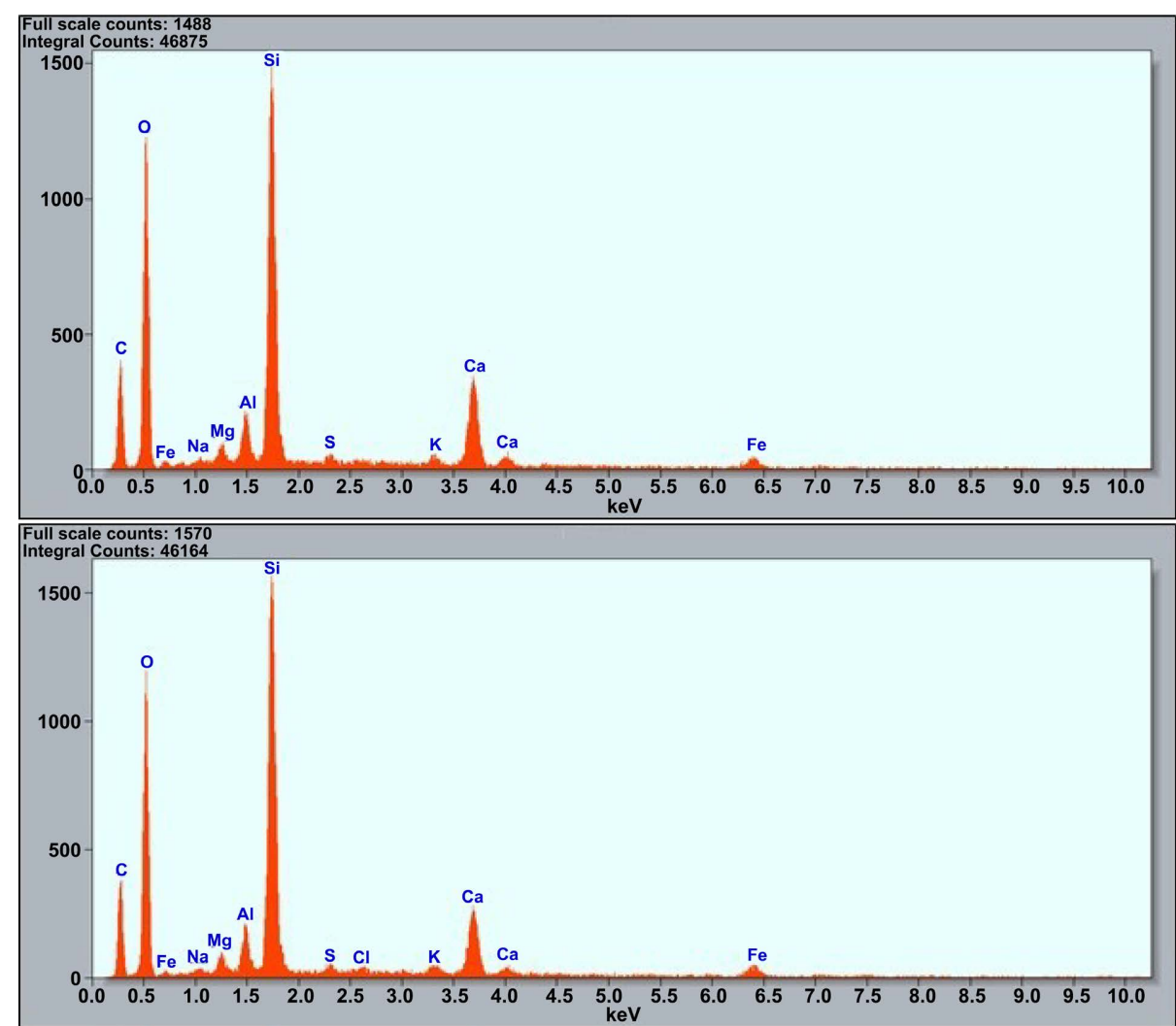

Figure 10. Chemical composition of the Cap des trois Fourches diatomite obtained by SEM. 


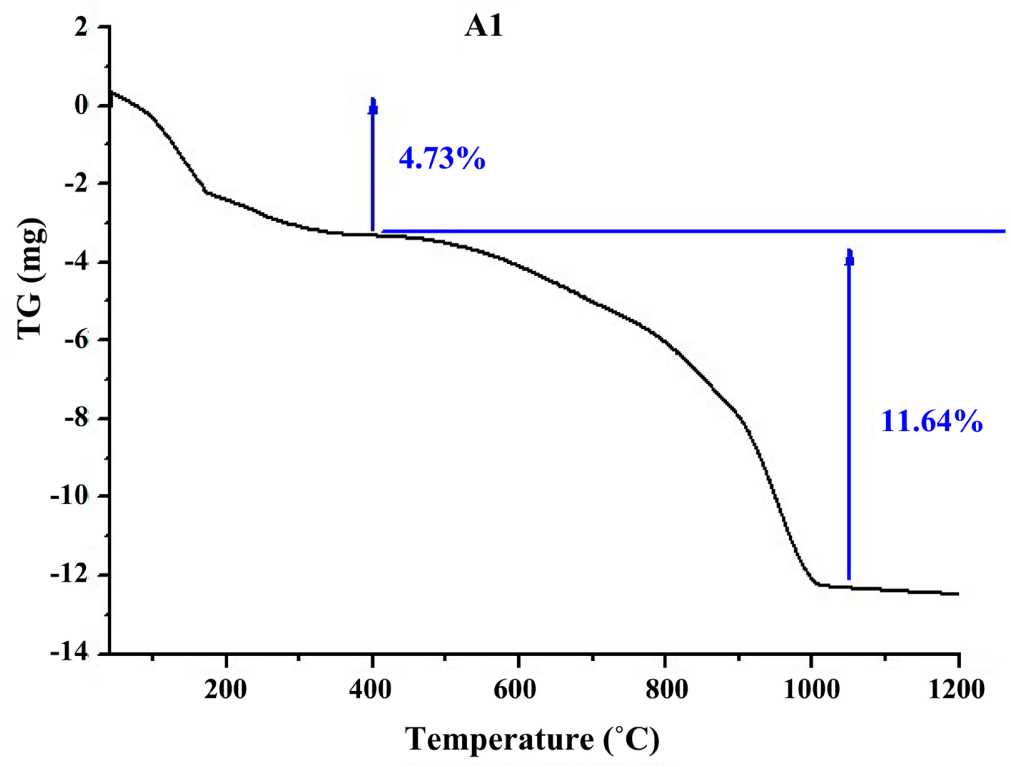

A2
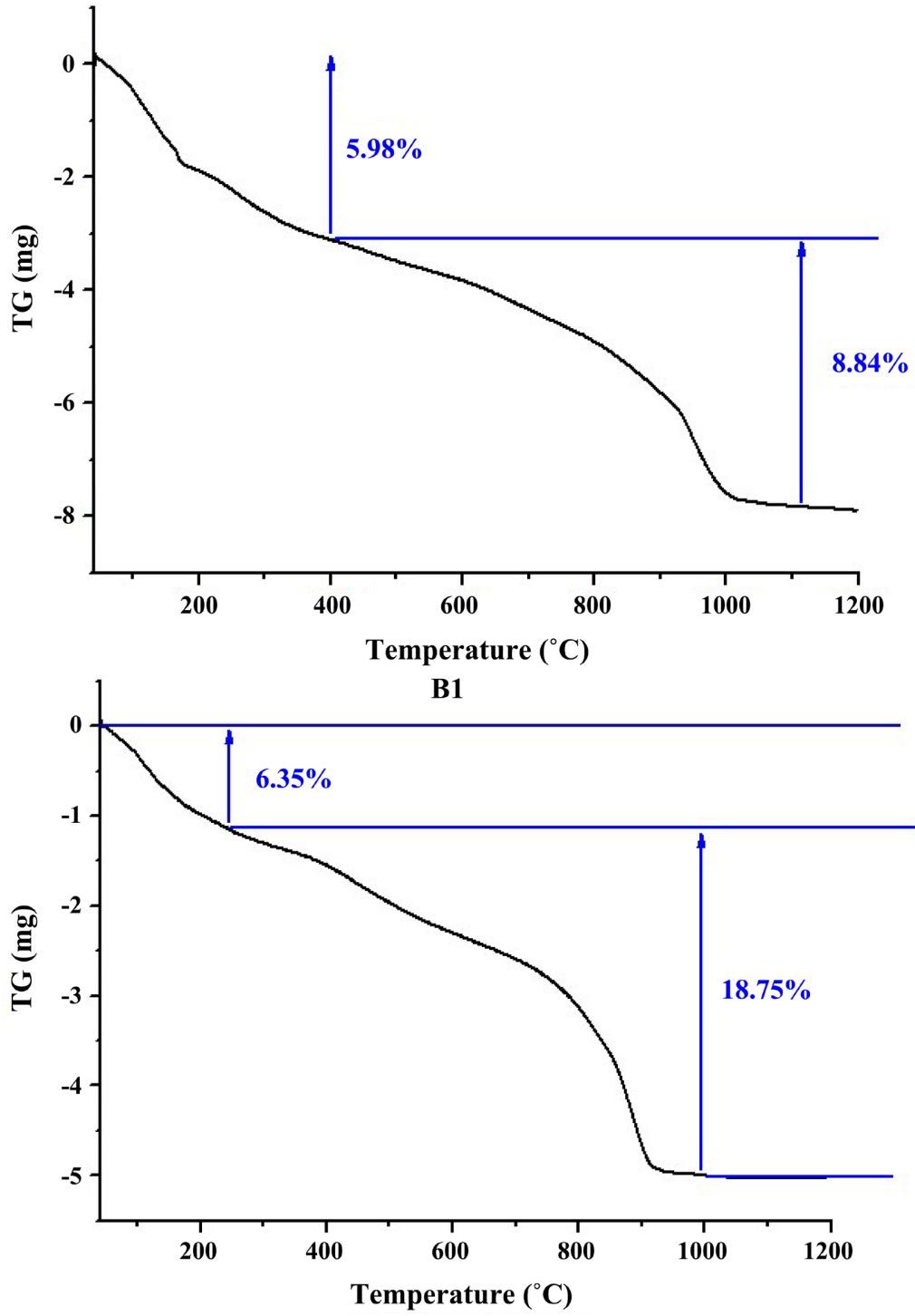


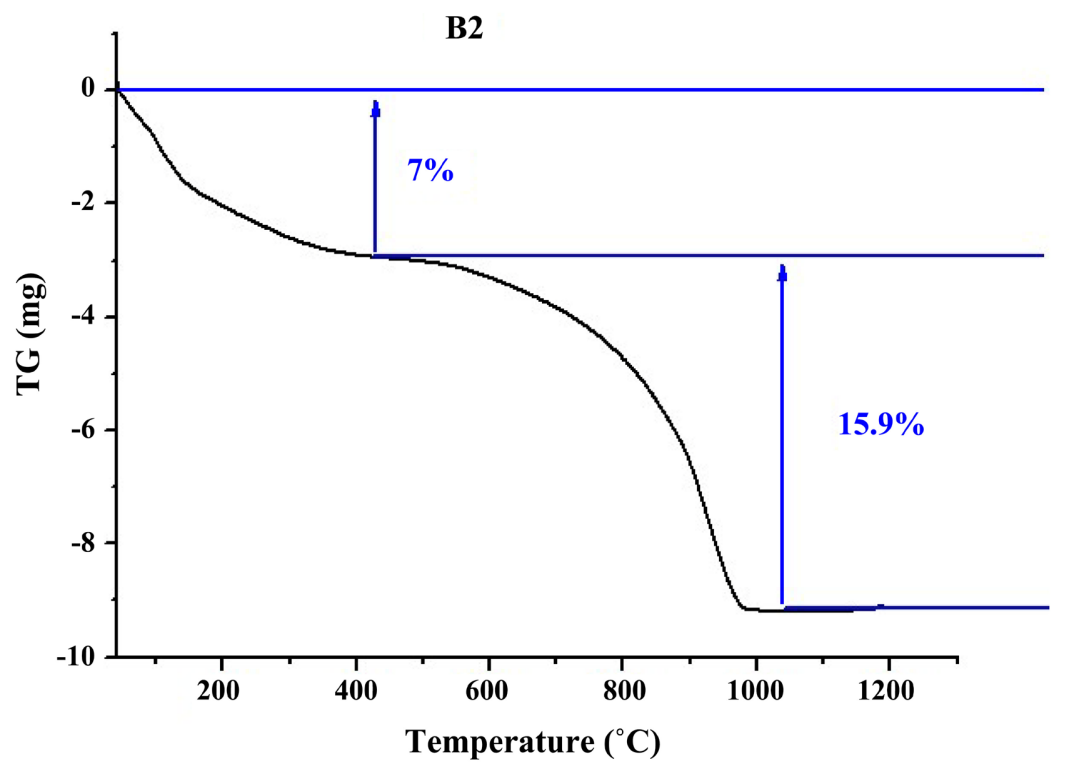

Figure 11. Thermogravimetric analyses on Boudinar crude diatomite (A1, A2) and Cap des trois Fourches (B1, B2).

des trois Fourches samples, two mass losses were observed for sample B1 at $410^{\circ} \mathrm{C}(7 \%)$ and at $1300^{\circ} \mathrm{C}(15.9 \%)$. While sample B2, exhibited the first loss of mass at $280^{\circ} \mathrm{C}(6.35 \%)$ and the second at $1000^{\circ} \mathrm{C}(18.75 \%)$.

\section{Discussion}

In this section, we will discuss the various analytical results that have been obtained. In fact, as mentioned before, the analytical programme aimed to characterise raw diatomite from different deposits and by various methods. The physico-chemical characterisation of diatomites was performed by using X-ray diffraction to determine the mineralogy of the diatomite, scanning electron microscopy to obtain information on the morphology of the diatomite particles, infrared spectroscopy to detect the structural groups present and thermogravimetric analysis to follow the thermal comportment of the diatomite. The objective is to determine the geochemical and textural characteristics for the different diatomite deposits of north-eastern Morocco in order to establish a dataset with the different properties of these materials that can be used to orient their utilisation.

The granulometric analysis of the crude diatomite from the North-Eastern Morocco deposits reveals that this material is mainly composed of fine grains with an average size lower than $63 \mu \mathrm{m}$ (Figure 2). This structure could show that this sediment is formed essentially from juxtapositions of diatom frustules, which are generally very small in size. The calcimetric study shows two types of facies: *the carbonated diatomite of the Cap des trois Fourches $\left(\mathrm{CaCO}_{3}\right.$ content is $28 \%$ ); ${ }^{\star}$ the less carbonated diatomite of Boudinar and Zeghanghane (contents vary between $3 \%$ and $14 \%$ ) (Figure 3 ). The change in carbonate content is an important element that influences the purity of the material and consequently its exploitation domain (Rocher, 1995, Ivanov \& Belyakov, 2008). Therefore, it is 
clear that diatomite exploitation from Cap des Trois Fourches requires prior treatment to remove impurities and improve its quality. The $\mathrm{pH}$ values of the raw diatomite from the studied deposits oscillate between 7.61 and 7.83 (Figure 4). Moreover, $\mathrm{pH}$ is a predominant parameter in the adsorption process. It directly affects the charge state of the adsorbent and the adsorbate. His effect on contaminants retention is often studied. Commonly, a low $\mathrm{pH}$ favours the adsorption of anions while an alkaline environment supports the adsorption of cations (Bentahar, 2016; El Sayed, 2018; Valente Flores-Cano et al. 2013). Also, in highly alkaline environments, diatomite has a pozzolanic effect (Colin et al., 2018).

The mineralogical composition of the three types of diatomite showed that the samples studied generally have a comparable composition. Semi-quantitative analysis of the crude diatomite from the three deposits reveals that this material is composed mainly of silica in the form of quartz, cristobalite and amorphous silica; calcite and dolomite and clay minerals (Figure 5). This chemical composition is similar to that characterizing the natural diatomite of RasTarf (Zaitan et al., 2006) and Sig (Algeria) (Cherrak, 2018; Khaldi, 2019; Benzelmat et al., 2019).

The infrared infrared spectroscopy study is in agreement with the results revealed by X-ray diffraction analysis. The IR spectra obtained for the crude diatomite from the three deposits (Figure 6) provided information on the nature of the functional groups and the main molecular bonds that were present. Silica was observed for all three of the types of diatomites. The presence of carbonates and clay minerals was also detected. Similar results have been found by other researchers (Benzelmat et al., 2019; Khaldi, 2019).

Scanning electron microscope analysis of crude diatomite from two deposits in the North Eastern Rif (Boudinar and Cap des trois fourches) reveals that this material is mainly constituted of diatom tests possessing a circular shape with a multiporous structure (Figure 7 and Figure 8). In fact, a detailed micropalaeontological study of the Boudinar diatoms (El Ouahabi et al., 2007), showed that these microfossils present variable forms and are represented by 185 species (75 species of centrics and 110 species of pennate). The porous structure of raw diatomite is sometimes damaged by impurities such as: Carbonates and clays. This microstructure of the crude diatomite of the eastern North Rif is similar to that observed in diatomites from other regions (Al-degs, Khraisheh, \& Tutunji, 2001; Ivanov \& Belyakov, 2008; Stamatakisa \& Koukouzas, 2001; Yılmaz \& Ediz, 2008; Hadjadj-Aoula, Belabbesa, Belkadib, \& Guermouche, 2005; Koukouzas, 2007; Arik, 2003, Khaldi et al., 2018; Cherrak et al., 2020).

The results of the chemical composition obtained by SEM (Figure 9 and Figure 10), indicate that the crude diatomites are made up in large proportion of $\mathrm{Si}$ as shown by the large peak of silica, followed by $\mathrm{Al}, \mathrm{Ca}$ and $\mathrm{Mg}$ and in small quantities of $\mathrm{Fe}, \mathrm{Na}$ and $\mathrm{K}$. These complementary results are consistent with the results obtained by the other methods.

$\mathrm{X}$-ray Fluorescence is a technique commonly used to obtain quantitative in- 
formation about the chemical composition of material. Until we obtain the results of studied samples, we have exploited the results of previous work realised on the raw diatomites of the Rif. The chemical composition analysis of the Rif diatomite and its comparison with algerian diatomite is indicated in Table 1 . We have chosen to make comparisons with the Algerian diatomite because it is deposited in the same geodynamic context and during the same period.

Crude Diatomite chemical analysis of the Moroccan Rif shows the predominance of silica $\mathrm{SiO}_{2}(57.1 \%-72.8 \%)$, as well as the presence of calcium oxide $\mathrm{CaO}$ (5.3\% - 6.15\%), aluminium oxide $\mathrm{Al}_{2} \mathrm{O}_{3}\left(4.37 \%\right.$ - 9.63\%) and feroxide $\mathrm{Fe}_{2} \mathrm{O}_{3}$ $(1.94 \%-5.13 \%)$, while the other elements $\left(\mathrm{MgO}, \mathrm{Na}_{2} \mathrm{O}, \mathrm{K}_{2} \mathrm{O}, \mathrm{TiO}_{2}, \mathrm{ZrO}_{2}, \mathrm{SrO}_{3}\right)$ are very low (Table 1 ).

From this chemical composition, we can stipulate that the diatomite in the Rif deposit is relatively of good quality. It has approximately the same chemical composition as the Algerian one. However, it should be noted that the chemical composition of diatomite varies from one deposit to another in the same region.

Thermogravimetric analysis of the Boudinar samples (Figure 11) reveals two distinct mass losses: The first, slight, took place at $400^{\circ} \mathrm{C}$, it is of the order of $4.73 \%$ for $\mathrm{A} 1$ and $5.78 \%$ for $\mathrm{A} 2$, while the second, more significant loss is observed at $1070^{\circ} \mathrm{C}$. It corresponds to $11.64 \%$ for $\mathrm{A} 1$ and $8.84 \%$ for $\mathrm{A} 2$.

Two mass losses were observed for the samples from the Cap des trois Fourches, in sample $\mathrm{B} 1$ at $410^{\circ} \mathrm{C}(7 \%)$ and at $1300^{\circ} \mathrm{C}(15.9 \%)$, while sample $\mathrm{B} 2$, showed the first mass loss at $280^{\circ} \mathrm{C}(6.35 \%)$ and the second at $1000^{\circ} \mathrm{C}(18.75 \%)$.

This thermogravimetric analysis provides a good approach to the mass evolution of raw diatomite samples against temperature. As illustrated in Figure 11, it

Table 1. Chemical composition (\% by weight) of crude diatomite from the Rif and comparison with crude diatomite from Algeria.

\begin{tabular}{|c|c|c|c|c|c|}
\hline $\begin{array}{c}\text { Chemical } \\
\text { composition } \\
(\% \mathrm{P})\end{array}$ & $\begin{array}{l}\text { Raw diatomite } \\
\text { Boudinar } \\
\text { (preliminary } \\
\text { study El } \\
\text { Attmani, 2015) }\end{array}$ & $\begin{array}{l}\text { Rif crude } \\
\text { diatomite } \\
\text { (Zaitan et } \\
\text { al., 2006) }\end{array}$ & $\begin{array}{l}\text { Raw diatomite } \\
\text { Ras Tarf (Rif, } \\
\text { Morocco) } \\
\text { Haddad and } \\
\text { al., } 2001\end{array}$ & $\begin{array}{l}\text { Raw diatomite } \\
\text { Algeria } \\
\text { Benzelmat et } \\
\text { al, } 2019\end{array}$ & $\begin{array}{l}\text { Raw diatomite } \\
\text { Sig Algeria } \\
\text { (Khaldi-2019; } \\
\text { Cherrak, } \\
\text { 2018) }\end{array}$ \\
\hline $\mathrm{SiO}_{2}$ & 57.1 & 72.8 & 69.00 & 47.52 & 68.015 \\
\hline $\mathrm{Al}_{2} \mathrm{O}_{3}$ & 9.63 & 5.22 & 4.37 & 2.85 & 7.575 \\
\hline $\mathrm{CaCO}$ & 6.15 & 5.86 & 5.30 & 22.44 & 19.25 \\
\hline $\mathrm{MgO}$ & 2.28 & 1.13 & 1.08 & 1.21 & 1.241 \\
\hline $\mathrm{Fe}_{2} \mathrm{O}_{3}$ & 5.13 & 1.94 & 2.58 & 1.22 & 2.024 \\
\hline $\mathrm{Na}_{2} \mathrm{O}$ & 2 & 0.83 & 0.67 & 0.09 & 0.200 \\
\hline $\mathrm{K}_{2} \mathrm{O}$ & 0.898 & 0.901 & 1.80 & --- & 1.491 \\
\hline $\mathrm{TiO}_{2}$ & 0.263 & 0.27 & --- & ---- & 0.144 \\
\hline $\mathrm{ZrO}_{2}$ & 0.0109 & ---- & --- & --- & 0.007 \\
\hline $\mathrm{SrO}_{3}$ & 0.0164 & ----- & 0.10 & --- & 0.038 \\
\hline
\end{tabular}


is clear that the diatomite shows a significant mass loss amounting to $19 \%$. This confirms that diatomite is a humid and porous material (consisting mainly of amorphous silica). This would contribute to decreasing its thermal conductivity, improving its thermal insulation capacity. Studies on the thermal properties of diatomite have shown that this material could be used for thermal isolation (Balaska et al., 2013; Nakkad et al., 2005). According to this thermal performance, diatomite is moderately refractory, Colin et al. (2018) report that its softening point is between $1400^{\circ} \mathrm{C}$ and $1600^{\circ} \mathrm{C}$.

\section{Conclusion}

The objective of this work was the physico-chemical characterisation of diatomite from three deposits located in north-eastern Morocco in order to establish a dataset with the different properties of these sediments which can be used to guide the utilisation and exploitation of this material.

The study, based on various analytical techniques, shows that raw diatomite from North Eastern Morocco is a fine material, with an average size of less than $63 \mu \mathrm{m}$ and a $\mathrm{pH}$ that varies between 7.61 and 7.83. Calcimetric analysis highlights two types of facies: the carbonated diatomite of the Cap des trois fourches $\left(\mathrm{CaCO}_{3}\right.$ content is $\left.28 \%\right)$ and the less carbonated diatomite of Boudinar and Zeghanghane (contents vary between $3 \%$ and $14 \%$ ). The mineralogical determination of these materials by X-ray diffraction showed that all samples are composed mainly of silica in the form of quartz, cristobalite and amorphous silica. Other associated minerals were detected in these samples. The carbonate minerals such as dolomite and calcite were observed. In addition, clay minerals (Muscovite and Nontronite) are detected mainly in the Boudinar diatomite and the Cap des Trois Fourches.

The structural study of these diatomites by infrared spectroscopy revealed coherence with those obtained by XRD analyses. The presence of silica was well confirmed for the three types of diatomite. Carbonates and clay minerals were also detected.

Moreover, qualitative and quantitative analysis spectra obtained by SEM indicate that these samples are rich in diatom frustules, which gives this material a well-developed porosity and a high content of silica. Chemical composition results obtained by SEM indicate that the crude diatomites are composed of a large proportion of $\mathrm{Si}$ as illustrated by the large silica peak, followed by $\mathrm{Al}, \mathrm{Ca}$ and $\mathrm{Mg}$ and small quantity of $\mathrm{Fe}, \mathrm{Na}$ and $\mathrm{K}$. These complementary results are coherent with those obtained by other methods.

Thermogravimetric analysis informs about the mass evolution of raw diatomite samples against temperature. Results obtained clearly show that diatomite has a significant mass loss amounting to $19 \%$. This confirms that diatomite is a humid, porous and moderately refractory material.

This study allowed us to determine the geochemical and textural characteristics of three diatomite deposits that have been poorly studied to date. It hig- 
hlighted that these diatomites have attractive physico-chemical properties (high silica content, lightweight, porosity, insolubility, chemical inertia, etc.) and are relatively similar to those found in other regions (Algeria, Spain, Greece, ...). Through this study, we have also provided a series of data that can orient the utilisation of this material, abundant but poorly exploited in Morocco. This work opens new perspectives on the studied material. And we will envisage extending and improving the physic-chemical characterisation of all the Moroccan diatomite deposits.

\section{Acknowledgements}

The authors would like to thank the responsible of the National Center for Scientific and Technical Research in Rabat (CNRST) Morocco, the director of the analysis center of the Faculty of Sciences Ben M'Sik and the director of the laboratory Geosciences and applications, Faculty of Sciences Ben M'Sik, Hassan II University of Casablanca, Morocco. We also thank the reviewers and editors of this journal.

\section{Conflicts of Interest}

The authors declare no conflicts of interest regarding the publication of this paper.

\section{References}

Achalhi, M., Münch, Ph., Cornée, J.-J., Azdimousa, A., Melinte-Dobrinescu, M., Quillévéré, F., Drinia, H., Fauquette, S., Jiménez-Moreno, G., Merzeraud, G., Ben Moussa, A., El Kharim, Y., \& Feddi, N. (2016). The Late Miocene Mediterranean-Atlantic Connections through the North Rifian Corridor: New Insights from the Boudinar and Arbaa Taourirt Basins (North Eastern Rif, Morocco). Palaeogeography, Palaeoclimatology, Palaeoecology, 459, 131-152. https://doi.org/10.1016/j.palaeo.2016.06.040

Agdi, K., Bouadi, A., Estban, A. M., Hemando, P. F., Azmania, A., \& Camara C. (2000). Removal Ofatrazine and Four Organophosphorus Pesticides from Environmental Waters by Diatomaceous Earth-Remediation Method. Journal of Environnmental Monitoring, 2, 420-423. https://doi.org/10.1039/B004740F

Al-Degs, Y., Khraisheh, M. A. M., \& Tutunji, M. F. (2001). Sorption of Lead Ions on Diatomite and Manganese Oxides Modified Diatomite. Water Research, 35, 3724-3728. https://doi.org/10.1016/S0043-1354(01)00071-9

Arik, H. (2003). Synthesis of $\mathrm{Si}_{3} \mathrm{~N}_{4}$ by the Carbo-Thermal Reduction and Nitridation of Diatomite. Journal of the European Ceramic Society, 23, 2005-2014. https://doi.org/10.1016/S0955-2219(03)00038-4

Azdimousa, A., Poupeau, G., Rezqi, H., Asebry, L., Bourgois, J., \& Ait Brahim, L. (2006). Géodynamique des bordures méridionales de la mer d'Alboran; Application de la stratigraphie séquentielle dans le bassin néogène de Boudinar (Rif oriental, Maroc). Bulletin de I'Institut Scientifique, Rabat, 28, 9-18.

Bahramian, B., DoulatiArdejanib, F., Mirkhanic, V., \& Badiid, K. (2008). Diatomite-Supported Manganese Schiff Base: An Efficient Catalyst for Oxidation of Hydrocarbons. Applied Catalysis A: General, 345, 97-103. 
https://doi.org/10.1016/j.apcata.2008.04.028

Balaska, A., Hamouda, A., Meradi, H., \& Rahmani, K. (2013). Caractérisation des matériaux utilisés en isolation thermique dans la coulée continue de l'acier. In Deuxième Conférence Internationale sur la Maintenance et la Sécurité Industrielle Skikda. Algérie CIMSI.

Barhoun, N. (2000). Biostratigraphie et paléo-environnement du Miocène supérieur et du Pliocène inférieur du Maroc septentrional: Apport des foraminifères planctoniques (p. 272). Thèse Doct. Etat. Univ. Hassan II-Mohammedia.

Barhoun, N., \& Wernli, R. (1999). Biostratigraphie du Mio-Pliocène du bassin de Boudinar par les foraminifères planctoniques (Rif nord-oriental, Maroc). Revue de Paléobiologie, 18, 491-508.

Ben Moussa, A. (1994). Les Bivalves néogènes des secteurs occidental et oriental du Maroc septentrional (Façade Atlantique et méditerranéenne). Biostratigraphie, paléobiogéographie et paléoécologie (No. 132, 281 pp.). Documents des Laboratoires de Géologie de Lyon.

Bentahar, Y. (2016). Caractérisation physico-chimique des argiles marocaines: Application à l'adsorption de l'arsenic et des colorants cationiques en solution aqueuse. Thèse de Doctorat de l'universite Abdelmalek Essaadi, Tétouan.

Benzelmat, L. A., Cherraka, R., Hadjel, M., Ketteb, A., \& Goual, N. (2019). Characterization between crude diatomite and diatomite Treated chemically. Algerian Journal of Environmental Science and Technology, 5, 1107-1112.

Breese, O. Y. (1994). Diatomite. In Industrial Minerals and Rocks (6th ed., pp. 397-412).

Cherrak, R. (2018). Valorisation d'un catalyseur nano composite et son application pour la dégradation photocatalytique des polluants organiques. Doctorat en sciences de l'université Abdelhamid Ibn badis-Mostaganem, faculté des sciences et de la technologie. Algérie.

Cherrak, R., Hadjel, M., Benderdouche, N., Adjdir, M., Mokhtar, A., Khaldi, K., Sghier, A., \& Weidler, P. G. (2020). Preparation of Nano- $-\mathrm{TiO}_{2} /$ Diatomite Composites by Non-hydrolytic Sol-Gel Process and its Application in PhotocatalyticDegradation of Crystal Violet. Silicon, 12, 927-935. https://doi.org/10.1007/s12633-019-00186-6

Colin, S., Charles, N., \& Lefebvre, G. (2018). Diatomite Mémento. Technical Report, Bureau de Recherches Géologiques et Minières.

Cornée, J. J., Münch, P., Achalhi, M., Merzeraud, G., Azdimousa, A., Quillévéré, F., Melinte-Dobrinescu, M., Chaix, C., Ben Moussa, A., Lofi, J., Séranne, M., \& Moissette, P. (2016). The Messinian Erosional Surface and the Early Pliocene Reflooding in the Alboran Sea: New Insights from the Boudinar Basin, Morocco. Sedimentary Geology, 333, 115-129. https://doi.org/10.1016/j.sedgeo.2015.12.014

Cornée, J. J., Saint Martin, J. P., Conesa, G., Muller, J., \& Andre, J. P. (1996). Anatomie de quelques plates-formes progradantesmessiniennes de Méditerranée occidentale. Bulletin de la Société géologique de France, 167, 495-507.

Cornée, J.-J., Roger, S., Münch, P., Saint Martin, J.-P., Féraud, G., Conesa, G., \& Pestrea-Saint Martin, S. (2002). Messinian Events: New Constraints from Sedimentological Investigations and New 40Ar/39Ar Ages in the Melilla-Nador Basin (Morocco). Sedimentary Geology, 151, 127-147. https://doi.org/10.1016/S0037-0738(01)00235-4

El Attmani, M. (2015). Caractérisation physico-chimique de la diatomite messinienne (Maroc Nord oriental): Applications dans le traitement des eaux (étude préliminaire). Rapport Master, Hassan II University of Casablanca (inédit). 
El Hajjaji, Kh. (1992). Les bryozoaires du miocène supérieur du Maroc nord oriental. Documents des laboratoires de géologie, Lyon, 117, 1-153.

El Kharim, Y. (1991). Sédimentologie et palynologie du Néogène du bassin de Boudinar: implications paléogéographiques et paléoclimatiques (Rif nord-oriental, Maroc) (No. 117, p. 153). Documents des Laboratoires de Géologie de Lyon.

El Ouahabi, F. Z., Saint Martin, S., Saint Martin, J.-P., Ben Moussa, A., \& Conesa, G. (2007). Les assemblages de diatomées du bassin messinien de Boudinar (Maroc nord-oriental). Revue de micropaleontology, 50, 149-167. https://doi.org/10.1016/j.revmic.2007.02.004

El Sayed, E. E. (2018). Natural Diatomite as an Effective Adsorbent for Heavy Metals in Water and Wastewater Treatment (a Batch Study). Water Science, 32, 32-43. https://doi.org/10.1016/j.wsj.2018.02.001

Guillemin, M., \& Houzay, J. P. (1982). Le Néogène post-nappe et le Quaternaire du Rif nord-oriental (Maroc). Stratigraphie et tectonique des bassins de Melilla, du Kert, de Boudinar et du piedmont des Kebdena. Notes et Mémoires du Service Géologique du Maroc, 314, 237-238.

Haddad, M., Boudlich, D., Archidi, M. E., Bentayeb, A., \& Nadiri A. (2001). CARACTERISATION DE DIATOMITES D'ORIGINE MAROCAINE PAR RPE DE $\mathrm{Fe}^{3+}$ ET $\mathrm{Mn}^{2+}$. Physical and Chemical News, 3, 36-38.

Hadjadj-Aoula, O., Belabbesa, R., Belkadib, M., \& Guermouchec, M. H. (2005). Characterization and Performances of an Algerian Diatomite-Based Gaschromatography Support. Applied Surface Science, 240, 131-139. https://doi.org/10.1016/j.apsusc.2004.06.108

Houzay, J. P. (1975). Géologie du bassin de Boudinar (Rif Oriental Maroc) (227 p). Thèse Cycle, Univ. Paris VI.

Ibrahim, S., \& Selim, A. Q. (2011). Evaluation of Egyptian Diatomite for Filteraid Applications. Physicochemical Problems of Mineral Processing, 47, 113-122.

Ivanov, S. É., \& Belyakov, A. V. (2008). Diatomite and Its Applications. Glass and Ceramics, 65, 48-51. https://doi.org/10.1007/s10717-008-9005-6

Khaldi, K. (2019). Elimination de polluants en milieu aqueux par matériaux aluminosilicates d'origine algérienne: Diatomite et diatomite activée. Thèse de Doctorat, de l'université des sciences et technologie d'Oran.

Khaldi, K., Hadjel, M., \& Benyoucef, A. (2018). Removal of Quinmerac by Diatomite and Modified Diatomite from Aqueous Solution. Surface Engineering and Applied Electrochemistry, 54, 194-202. https://doi.org/10.3103/S1068375518020084

Koukouzas, N. (2007). Mineralogy and Geochemistry of Diatomite Associatedwith Lignite Seams in the Komnina Lignite Basin, Ptolemais, Northern Greece. International Journal of Coal Geology, 71, 276-286. https://doi.org/10.1016/j.coal.2006.09.002

Liu, H., Lu, G., Guo, Y., Guo, Yu., \& Wang, J. (2004). Effect of Pretreatment on Properties of TS-1/Diatomite Catalyst Forhydroxylation of Phenol by $\mathrm{H}_{2} \mathrm{O}_{2}$ in Fixed-Bedreactor. Catalysis Today, 93-95, 353-357.

Nakkad, R., Ezbakhe, H., Benmoussa, A., Ajzoul, T., \& El bakkouri, A. (2005). Contribution à l'étude morphologique et thermique des diatomites utilisées dans l'isolation. In 12éme journée internationale de thermique. https://doi.org/10.1016/j.cattod.2004.06.083

Negroni, J.-M. (2007). Fiche détaillée relative à la diatomite. Guide des exploitants (3 p.). SIM.

Pellegrino, L., Dela Pierre, F., Natalicchio, M., \& Carnevale, G. (2018). The Messinian di- 
atomite deposition in the Mediterraneanregion and itsrelationships to the global silica cycle. Earth-Science Reviews, 178, 154-176.

https://doi.org/10.1016/j.earscirev.2018.01.018

Pestrea, S., Blanc-Valleron, M. M., \& Rouchy, J. M. (2002). Assemblages dediatomées du Messinien (Espagne, Sicile, Chypre). Geodiversitas, 24, 543-583.

Rachid, A., El Hajjaji, K., \& Civis, J. (1997). The Benthonic Foraminifera Associations of the Sidi Haj Youssef Marly-Diatomitic Section ( Messinian of Boudinar Basin, NE. Morocco). Geogaceta, 22, 173-176.

Rizki, K., Elmorabit, M., Ballouki, E. H., Mohsine, A., \& Toufik, H. (2003). Elimination des matières colorantes en suspension par filtration sur diatomite. Physical and Chemical News, 10, 94-99.

Rocher, Ph. (1995). Mémento roches et minéraux industriels-Diatomites. Bureau de Recherches Géologiques et Minières. Rap. BRGM R 38758, 62 p., 6 fig., 12 tabl.

Rouchy, J. M. (1982). La genèse des évaporites messiniennes de Méditerranée (267 p). Muséum national d'Histoire naturelle.

Rouchy, J. M., \& Freneix, S. (1979). Quelques gisements messiniens de Bivalves (Formation des Tripolis d'Algerie et du Maroc). Signification paléoécologique. Annales Géologiques des Pays Helléniques, 3, 1061-1107.

Sahraoui, H., Abouarnadasse, S., \& Allali, N. (2002). Utilisation d'argiles et diatomite d'origine marocaine comme supports de phases actives $\left(\mathrm{CR}_{2} \mathrm{O}_{3}\right.$ et nio) dans la réaction de décomposition de l'isopropanol. Physical and Chemical News, 7, 110-116.

Saint Martin, J. P., \& Rouchy, J. M. (1990). Les plates-formes carbonatées en Méditerranée occidentale: Leur importance pour la reconstitution des variations du niveau marin au Miocène terminal. Bulletin de la Société géologique de France, 6, 83-94. https://doi.org/10.2113/gssgfbull.VI.1.83

Saint Martin, S., Conesa, G., \& Saint Martin, J. P. (2003). Signification paléoécologique des assemblages de diatomées du Messinien dans le bassin de Melilla-Nador (Rif Nord-Oriental, Maroc). Revue de micropaléontologie, 46, 161-190. https://doi.org/10.1016/S0035-1598(03)00027-8

Stamatakisa, M. G., \& Koukouzasb, N. K. (2001). The Occurrence of Phosphate Minerals in Lacustrine Clayey Diatomite Deposits, Thessaly, Central Greece. Sedimentary Geology, 139, 33-47. https://doi.org/10.1016/S0037-0738(00)00154-8

Valente Flores-Cano, J., Leyva-Ramos, R., Padilla-Ortega, E., \& Barron, J.-M. (2013). Adsorption of Heavy Metals on Diatomite: Mechanism and Effect of Operating Variables. Adsorption Science \& Technology, 31, 275-291. https://doi.org/10.1260/0263-6174.31.2-3.275

Van Assen, E., Kuiper, K. F., Barhoun, N., Krijgsman, W., \& Sierro, F. J. (2006). Messinian Astrochronology of the Melilla Basin: Stepwise Restriction of the Mediterranean-Atlantic Connection through Morocco. Palaeogeography, Palaeoclimatology, Palaeoecology, 238, 15-31. https://doi.org/10.1016/j.palaeo.2006.03.014

Wernli, R. (1988). Micropaléontologie du Néogène post-nappes du Maroc septentrional et description systématique des foraminifères planctoniques. In Mining and Geological Map Service, Notes et mémoires du Service géologique (No. 331, p. 270). Editions du Service géologique du Maroc.

Yllmaz, B., \& Ediz, N. (2008). The Use of Raw and Calcined Diatomite in Cement Production. Cement and Concrete Composites, 30, 202-211.

https://doi.org/10.1016/j.cemconcomp.2007.08.003 
Zaitan, H., Feronnato, C., Bianchi, D., Achak, O., \& Chafik, T. (2006). Étude des propriétés texturales et adsorbantes d'une diatomite marocaine: Application au traitement d'air charge d'un polluant de type compose organique volatile. Annales de Chimie Science des Matériaux, 31, 183-196. 